GEOLOGICAL SURVEY CIRCULAR 814

\title{
Isolation of Uranium Mill \\ Tailings and Their \\ Component Radionuclides \\ From the Biosphere-Some \\ Earth Science Perspectives
}





\section{Isolation of Uranium Mill Tailings}

and Their Component Radionuclides From the Biosphere-Some Earth Science Perspectives

By Edward Landa

GEOLOGICAL SURVEY CIRCULAR 814

A critical review of the literature dealing with uranium mill tailings, with emphasis on the geologic and geochemical processes affecting the long-term containment of radionuclides 


\section{United States Department of the Interior}

CECIL D. ANDRUS, Secretary

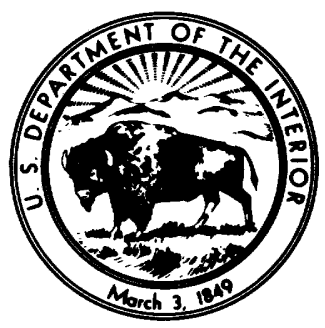

\section{Geological Survey}

H. William Menard, Director

Library of Congress catalog-card No. 79-600148 


\section{CONTENTS}

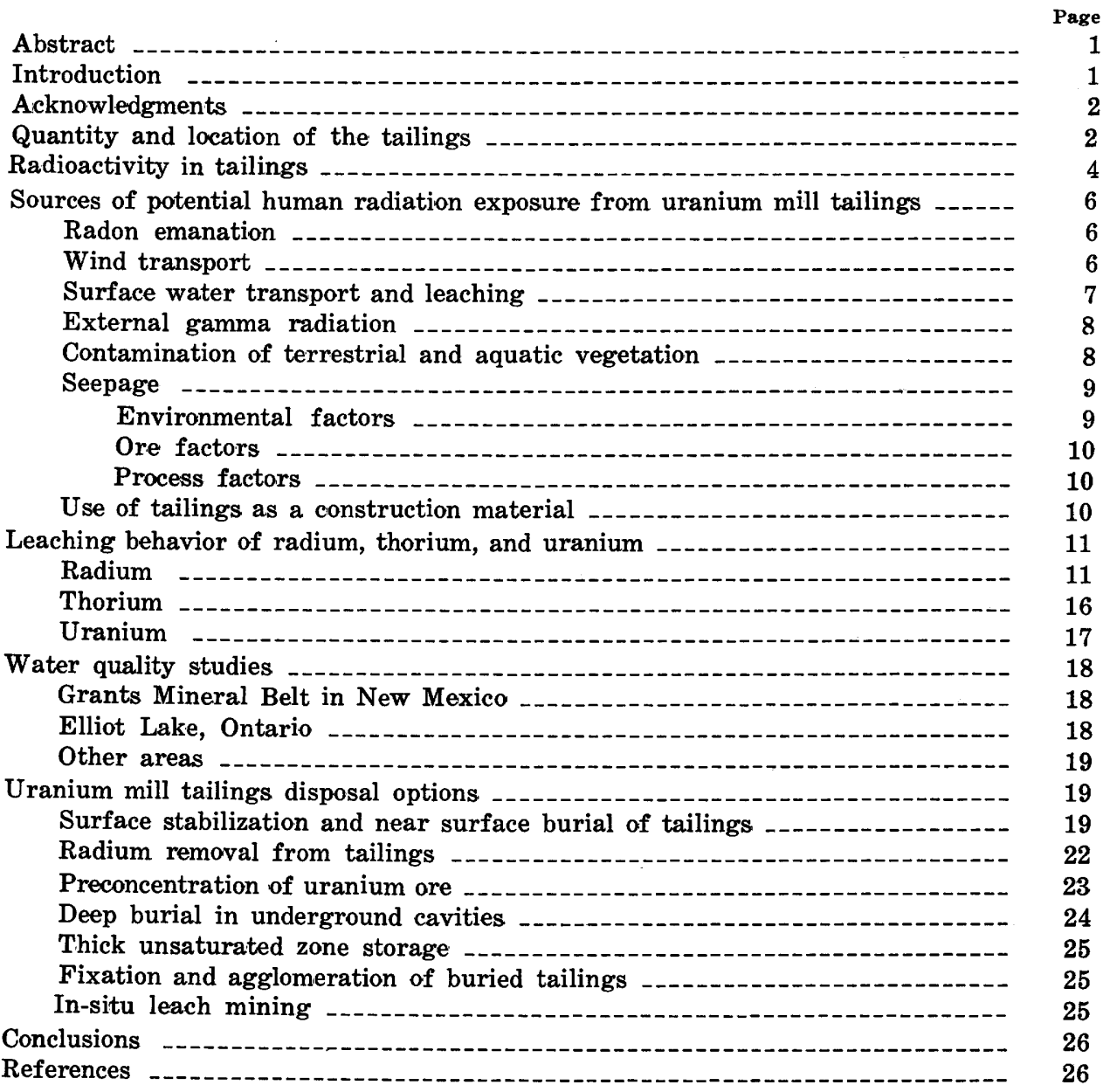

\section{ILLUSTRATIONS}

FIGURE 1. Map showing the location of active and inactive conventional uranium milling sites in the United States

2. Diagram showing the radioactive decay scheme of uranium-238

\section{TABLES}

TABLE 1. Water quality standards associated with uranium-238 decay series radionuclides

2. Proportion of radium-226 leached from uranium ore, uranium mill tailings, and river bottom sediments in laboratory tests 



\title{
Isolation of Uranium Mill Tailings and Their Component Radionuclides From the Biosphere- Some Earth Science Perspectives
}

\author{
By Edward Landa
}

\begin{abstract}
Uranium mining and milling is an expanding activity in the Western United States. Although the milling process yields a uranium concentrate, the large volume of tailings remaining centains about 85 percent of the radioactivity originally associated with the ore. By virtue of the physical and chemical processing of the ore and the redistribution of the contained radionuclides at the Earth's surface, these tailings constitute a technologically enhanced source of natural radiation exposure. Sources of potential human radiation exposure from uranium mill tailings include the emanation of radon gas, the transport of particles by wind and water, and the transport of soluble radionuclides, seeping from disposal areas, by ground water. Due to the 77,000 year half-life of thorium-230, the parent of radium-226, the environmental effects associated with radionuclides contained in these tailings must be conceived of within the framework of geologic processes operating over geologic time. The magnitude of erosion of cover materials and tailings and the extent of geochemical mobilization of the contained radionuclides to the atmosphere and hydrosphere should be considered in the evaluation of the potential, long-term consequences of all proposed uranium mill tailings management plans.
\end{abstract}

\section{INTRODUCTION}

Uranium mill tailings represent a unique type of radioactive waste. Rather than manmade materials containing fission products, activation products, and (or) transuranic elements, these tailings are earth materials containing radionuclides naturally present in the Earth's crust that have been brought to the surface, subjected to physical and chemical processing, and subsequently exposed to the action of surficial geologic processes. Thus redistributed, these radionuclides constitute a source of "technologically enhanced natural radiation exposure" ${ }^{1}$ to the surrounding population.

The philosophy expressed by Lush and others (1978) is worth considering with regard to the long-term storage of uranium mill tailings:

The development of a long-term waste management philosophy requires the acceptance of a basic set of management criteria. Our societies' approach has, as its basic tenets, that the present generation of waste managers should leave the wastes in such a manner that there is no foreseeable threat to future generations and future generations will not have to be involved in the care of the wastes. Implied is that the future bleed rate of contaminants from waste management sites should not exceed present regulatory levels, and not rely on continued monitoring to demonstrate that fact ***. Any acceptable long term solutions must not rely solely on a social management system, but rather on a management controlled by those basic geochemical and biochemical cycles which have been determining the flux rates of radionuclides through the open environment during the evolution of life on Earth.

In order to develop a management system which meets these criteria, a basic knowledge is needed of (a) those geochemical and biochemical reactions affecting the mobility of radionuclides, (b) the form into which those radionuclides are transformed during the milling and waste treatment operation, and (c) the consequences of this transformation as related to their mobility within and the flux rate from the waste management area over geological time. Only through an understanding of these processes and their interactions with the waste management environment can we determine whether present or future management areas

\footnotetext{
${ }^{1}$ Gesell and Prichard (1975) have defined "technologically enhanced natural radiation exposures" as exposures to truly natural sources of radiation (naturally occurring isotopes and cosmic radiation) which would not have occurred without (or would have been increased by) some technological activity not expressly designed to produce radiation.
} 
will transcend smoothly the cessation of active management and determine whether future passivelymanaged bleed rates acceptable under present day and hopefully future standards are achieved.

The purpose of this report is to document some of the existing information relevant to environmental mobilization, and to discuss the efficacy of various uranium mill tailings disposal options in light of potential mobilization mechanisms. While the emphasis here is on the potential, long-term consequences of tailings disposal, this view is in no way meant to detract from the very major advances in uranium mill tailings management, fostered by both the uranium industry and regulatory authorities, which have occurred in the past 2 decades. In the early years of uranium milling, only limited attention was paid to the now better-understood, environmental effects associated with radioactivity in the residual materials. In the late 1950's and early 1960's, work by the U.S. Pubic Health Service and others provided the impetus for controls on the discharge of mill effluents and initiation of stabilization efforts at tailings piles. The Grand Junction experience with the use of tailings for construction purposes spurred renewed interest in tailings management during the late 1960's and early 1970's. An examination of the environmental reports and statements prepared by mill operators and regulatory agencies over the last few years reflects the increasing awareness of the potential hazards associated with these tailings and the application of technology to mitigate these effects. The past 2 years represent a period of intense effort in this area, as: seen with the promulgation by the U.S. Nucear Regulatory Commission of siting, design, operation and reclamation criteria for the management of uranium mill tailings (U.S. Nuclear Regulatory Commission, 1977a), and the Commission's preparation of a generic environmental impact statement on the U.S. uranium milling industry to the year 2000 (U.S. Nuclear Regulatory Commission, 1979a). Also, the 95th Congress enacted the Uranium Mill Tailings Radiation Control Act of 1978 (Public Law 95604) providing for the reclamation of inactive uranium mill tailings areas, and the control of tailings as a licensed by-product material. The reader is thus cautioned to keep this historical and evolutionary perspective in mind. Examples from the past are presented as they are useful in understanding the behavior of uranium mill tailings in the environment. However, examples of past mismanagement should not be confused with current management practices.

A discussion of potential health impacts from uranium mill tailings is beyond the scope of this report; the reader is referred to Sears and others (1975), Ramsey (1976), Ford, Bacon, and Davis Utah, Inc. (1978), Travis and others (1979), and U.S. Nuclear Regulatory Commission (1979a) for an overview of the subject.

\section{ACKNOWLEDGMENTS}

The author wishes to acknowledge the efforts of Elise Passentino, Isaac Winograd, and members of the technical staffs of the U.S. Environmental Protection Agency, the U.S. Nuclear Regulatory Commission, and the U.S. Department of Energy and its contractors in reviewing this circular.

\section{QUANTITY AND LOCATION OF THE TAILINGS}

Most uranium ores being mined in the United States are sandstones, but limestones and lignites are also of importance (Reed and others, 1976). Milling consists of the mechanical and chemical processes that concentrate the uranium fraction from the ore. In conventional uranium milling, the ore is crushed and leached with either alkali or acid. Ores with the limestone contents greater than 15 percent are generally leached under alkaline conditions using sodium carbonate-bicarbonate, while most other ores are leached with sulfuric acid. The uranium extracted by the leaching solution is concentrated by solvent extraction or ion exchange, and subsequent precipitation (generally with ammonia) of a uranium concentrate (80-85 percent $\mathrm{U}_{3} \mathrm{O}_{8}$ ) that is referred to as "yellowcake." The leached ore residues, "tailings," are slurried with mill waste solutions and pumped to an earthen retention pond.

As the ores being exploited in the United State today generally contain only about 0.1 0.2 percent $\mathrm{U}_{3} \mathrm{O}_{8}$, essentially all of the tonnage 
of ore processed at the mill is deposited in the tailings pond. With current mill capacities ranging up to 7,000 metric tons of ore per day (Reed and others, 1976), the magnitude of the tailings thus generated is apparent. At present, there are in excess of 100 million metric tons of uranium mill tailings in the United States. Dependent upon the growth pattern projected for the United States nuclear industry, and its reliance on domestic uranium sources, this solid waste inventory is estimated to increase to between 0.9 and 1.7 billion metric tons by the year 2000 (Argonne National Laboratory, 1978; Adam and Rogers, 1978). Assuming a bulk density for the tailings of $1.7 \mathrm{~g} / \mathrm{cm}^{3}$ (Adam and Rogers, 1978), this latter quantity amounts to a volume of about one billion cubic meters. This volume would cover Washington, D.C., to a depth of about $5.8 \mathrm{~m}$ (19 ft).

Most uranium mining and milling to date has been in the Western States, especially in New Mexico, Colorado, Wyoming, Utah, and Texas (fig. 1). The bulk of these mills use conventional ore sources; however, active operations in Texas and Wyoming produce yellowcake from in-situ uranium leach solutions. Also, uranium is, or soon will be, recovered from phosphoric acid plants in Florida and Louisiana and from copper dump leach operations in Utah (Anonymous, 1978). As our reserves of higher grade ores becomes depleted, the mining and milling of lower grade and refractory materials such as described by Mutschler and others (1976) and Maysilles and others (1978) will undoubtedly increase. Also, the nationwide exploration activities associated with the U.S. Department of Energy's National Uranium Resource Evaluation (NURE) program may uncover new deposits. Thus, the areal extent of uranium mining and milling activities in the United States might be expected to increase in the coming decades.

The tailings disposal sites may be broadly grouped into inactive and active milling categories. The tailings at the inactive sites generally exist as piles atop the land surface which are either exposed or covered by $0.15-0.6 \mathrm{~m}$

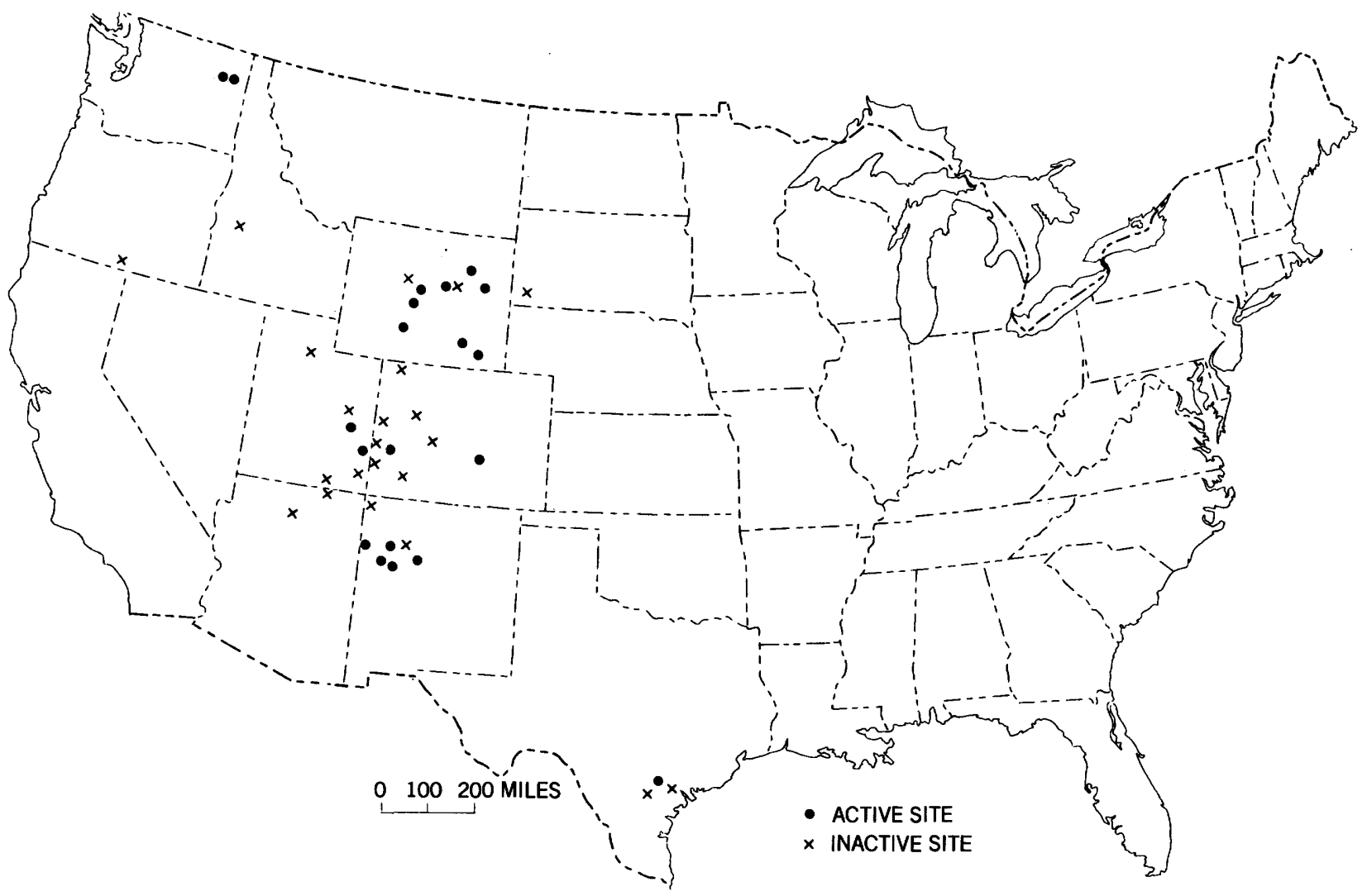

FIGURE 1.-Location of active and inactive conventional uranium milling sites in the United States. 
(0.5-2 ft) of soil (Ford, Bacon, and Davis Utah, Inc. 1976 ; 1977). Under the provisions of the Uranium Mill Tailings Radiation Control Act of 1978, the majority of these inactive sites will be subject to remedial action under the direction of the U.S. Department of Energy. Based on the finding that uranium mill tailings may pose a potential and significant radiation health hazard to the public, this legislation calls for the stabilization and control of such tailings in a safe and environmentally sound manner in order to minimize or eliminate radiation health hazards to the public. The exact nature of this remedial action will be prescribed on a site-specific basis, in accordance with health and environmental criteria to be developed by the U.S. Environmental Protection Agency. Remedial-action options that were considered in engineering assessments of these sites prepared for the U.S. Department of Energy (Ford, Bacon, and Davis Utah, Inc., 1976; 1977) include on-site stabilization of the piles with 0.15 to $5.5 \mathrm{~m}(0.5$ to $18 \mathrm{ft})$ of cover earth, and removal of tailings from their present locations, and stabilization at alternative sites nearby. Remedial action at the inactive sites is likely to begin in the early 1980 s.

At the present time, the U.S. Nuclear Regulatory Commission (NRC) regulates the design and siting of uranium mill tailings disposal areas at active milling sites in nonAgreement States as part of its licensing and regulation of source material milling under the National Environmental Policy Act of 1969 and the Atomic Energy Act of 1954 (Hendrie, 1978). The Uranium Mill Tailings Radiation Control Act of 1978 amends the Atomic Energy Act of 1954 by designation of uranium mill tailings as a by-product material, and authorizes the NRC to insure that the management of these tailings is carried out in such a manner as deemed appropriate to protect the public health and safety, and the environment from associated radiological and non-radiological hazards. Applicants for the issuance of a license to construct and operate a uranium mill are generally required to have a reclamation plan that includes a cover of at least $3 \mathrm{~m} \mathrm{(10}$ $\mathrm{ft}$ ) of earth over the tailings. Waste management criteria call for siting the tailings disposal areas in locations which are remote from people, where disruption and dispersion by natural forces are eliminated or reduced to the maximum extent reasonably achievable (U.S. Nuclear Regulatory Commission, 1977a). Lining of disposal zones with compacted soil, asphalt, clay, or synthetic polymeric membranes may be required to reduce seepage of waste solutions. Disposal of tailings in open pit mines or specially excavated pits ("below grade") is now generally. favored over impoundment behind a dam, the common disposal practice of the past. To date, there have been no uranium mill tailings piles stabilized in a manner consistent with current NRC licensing requirements. Such activities are likely to begin in about 15 to 25 years, following the completion of active milling and after a postoperational drying period, at sites being licensed today.

\section{RADIOACTIVITY IN TAILINGS}

Naturally-occurring uranium contains 99.2830 percent (by weight) uranium-238, 0.7110 percent uranium-235, and 0.0054 percent uranium-234 (Hammond, 1970). Uranium ores commonly mined in the United States contain little thorium-282 (Haywood and others, 1977). Thus the bulk of the radioactivity in the ore, and hence in the yellowcake and tailings, is associated with uranium-238 and its progeny. The decay scheme of uranium-238 is shown in figure 2. The long-lived components of the decay chain, and hence those

TABLE 1.-Water quality standards associated with uranium-238 decay series radionuclides

[Concentrations (reported in picocuries/liter) as stipulated by indicated Federa] agencies]

\begin{tabular}{|c|c|c|}
\hline Radionuclide & $\begin{array}{c}\text { U.S. } \\
\text { Nuclear } \\
\text { Regulatory } \\
\text { Commission } \\
\text { (MPC w } \\
\text {-unrestricted } \\
\text { areas }^{1} \text { ) }\end{array}$ & $\begin{array}{c}\text { U.S. } \\
\text { Environmenta] } \\
\text { Protection } \\
\text { Agency } \\
\text { Interim } \\
\text { Primary } \\
\text { Drinking } \\
\text { Water } \\
\text { Regulations } 2\end{array}$ \\
\hline $\mathrm{U}-238$ & 40,000 & $\ldots$ \\
\hline U-234 & 30,000 & -- \\
\hline Th-230 & 2,000 & -- \\
\hline $\mathrm{Ra}-226$ & 30 & ${ }^{3} 5$ \\
\hline $\mathrm{Pb}-210$ & 100 & -- \\
\hline
\end{tabular}

\footnotetext{
1 Maximum permissible concentrations in water for unrestricted areas; Code of Federal Regulations, Title 10, pt. 20, Jan. 1, 1977. 2 Federal Register, v. 41, no. 133, July 9, 1976. Title 40, ch. 1

pt. 141 -Radionuclides.
3 Maximum of $5 \mathrm{pCi} / \mathrm{L}$ of combined $\mathrm{Ra}-226$ and $\mathrm{Ra}-228$.
} 


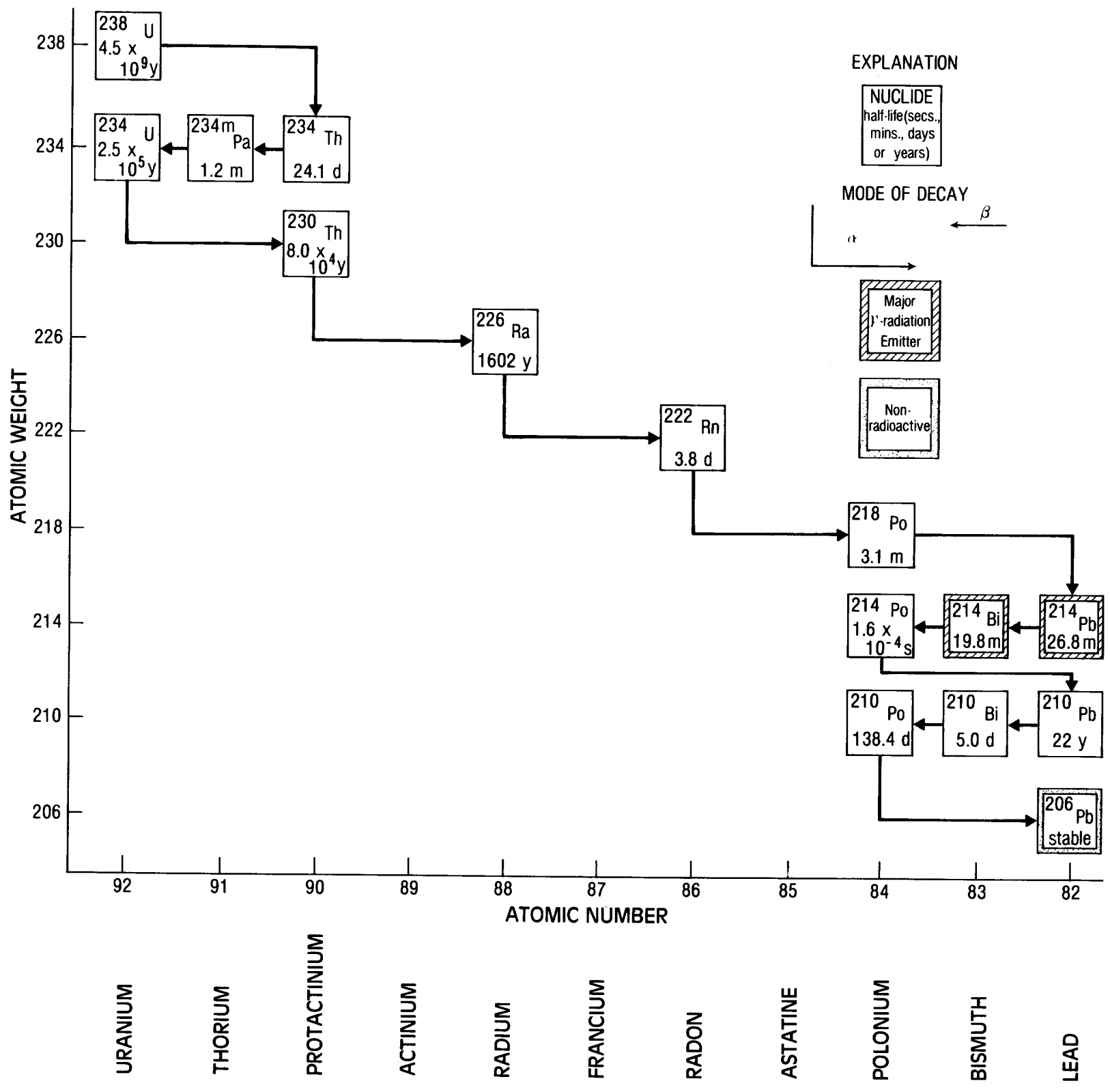

Figure 2.-The radioactive decay scheme of uranium-238. Only dominant decay modes are shown. (Adapted from U.S. Department of Health, Education and Welfare, 1970, and Motica, 1977).

of environmental concern (table 1), are uranium-238, uranium-234, thorium-230, radium226, and lead-210. Because the drinking water standards for radium-226 are the most restrictive (table 1), most monitoring and research efforts on the radiological impact of uranium mill tailings on surface- and ground-water quality have focused on this radionuclide. Assuming secular equilibrium, an ore containing 0.2 percent $\mathrm{U}_{3} \mathrm{O}_{8}$ will contain $0.00056 \mathrm{~g}$ of radium-226/metric ton of ore (U.S. Environmental Protection Agency, 1973). As in both acid and alkaline leaching, greater than 98 percent of the radium-226 remains with the tailings (Moffett, 1976); the tailings from such an ore will contain about 560 picocuries (pCi) of radium-226/g.

While about 90-95 percent of the uranium in the ore is extracted in the milling process, most of the uranium-daughter products, com- 
prising about 85 percent of the total radioactivity in the ore, remain with the tailings, which thus constitute a low-level radioactive waste material. The tailings are often classified into a coarse- and a fine-size fraction referred to as "sand" and "slime," respectively. The uranium-bearing minerals are generally softer than the bulk components of the host rock. Thus, crushing of the ore tends to concentrate the uranium and uranium-daughter products in the slime fractions. Borrowman and Brooks (1975) examined acid- and alkali-processed tailings and found that while the slime fraction made up only 25-27 percent by weight of the tailings, it contained 77-94 percent of the radium inventory. Slimes from the processing of ores from the Western United States may contain up to $3,000 \mathrm{pCi}$ of radium-226/g (Haywood and others, 1977).

Besides radionuclides, non-radioactive substances potentially detrimental to water quality may also be introduced into the surficial environment by activities associated with uranium milling. These substances may be present in the ore or in the process reagents. The process reagents may contribute chloride, nitrate, and sulfate (West, 1972; Clark, 1974), while the ores may contribute elements such as selenium, arsenic, molybdenum, and vanadium (U.S. Environmental Protection Agency, 1971; Clark, 1974).

Besides the leached ore residues, milling waste solutions (barren liquor from leach process with small amounts of entrained or soluble organic solvents) also enter the tailings retention pond. These waste streams contain soluble radionuclides that (1) may persist in solution and migrate in ground water, (2) may precipitate by interacting with components from other waste solutions or as a result of liming or other amendments, or (3) may be sorbed by the tailings or underlying soil in the retention pond. At the Bluewater uranium mill in New Mexico, waste effluents have in the past been disposed of by injection into a deep Permian aquifer containing non-potable water (West, 1972).

\section{SOURCES OF POTENTIAL HUMAN RADIATION EXPOSURE FROM URANIUM MILL TAILINGS \\ RADON EMANATION}

Radon-222 is the radioactive noble gas daughter product of Ra-226. Tailings from several acid-leach uranium mills in the United States have an emanating power (defined as that fraction of radon produced in a mineral matrix which escapes the matrix and is free to diffuse in the pore spaces) of about 10-20 percent (Ryon and others, 1977; Macbeth and others, 1978). Because of the short half-life of radon and the resultant radioactive decay of a portion of the radon released from the tailings particles during its diffusion through the pore spaces within the pile, the radon flux at the surface of the pile also depends upon the thickness, porosity, permeability, and moisture content of the tailings and any cover material. The relaxation length ${ }^{2}$ for radon diffusing through a dry sand is about $1.5 \mathrm{~m}$ (Tanner, 1964a; Schiager, 1974; Macbeth and others, 1978).

Most assessments of the radiological impact of uranium mill tailings have concluded that the inhalation of radon daughter products is the major source of radiation exposure associated with these materials (U.S. Environmental Protection Agency, 1973; Haywood and others, 1977; Adam and Rogers, 1978). As radon release from inactive, dry tailings piles may be 4 to 25 times greater than that from wet tailings ponds (Goldsmith and others, 1978; U.S. Environmental Protection Agency, 1973), the maximum radiological impact from this source may occur after mill operation ceases, but prior to burial. Radon emanation will persist for a period governed by decay of thorium-230 (half-life of 77,000 years), the longest-lived uranium-238 daughter product that remains with the tailings and that decays to radium-226, the parent of radon-222 (fig. 2).

\section{WIND TRANSPORT}

Ore crushing and yellowcake drying and packaging lead to the atmospheric suspension

\footnotetext{
2 The relaxation length is defined as the distance required to reduce the radon concentration by a factor of " $e$ ", where " $e$ " is the base of the natural logarithm system and has the approximate value of 2.72 .
} 
of radioactive dusts, which create inhalation hazards locally, and are subject to wind movement to off-site areas. With available dust control technology such exposure pathways can be minimized (U.S. Environmental Protection Agency, 1973; Sears and others, 1975).

Tailings exposed to the wind prior to burial, or as a result of the erosion of cover materials, will also be subject to wind transport. The quantity of the tailings thus mobilized will depend upon the characteristics of the wind (velocity, duration, and direction), the characteristics of the tailings (particle size and moisture content), and the location of the tailings within or upon the landscape. Final burial of tailings in pits below at least $3 \mathrm{~m}$ of earth, as presently recommended by the NRC, should greatly expand the period of protection of the tailings from wind transport as compared with that offered by the exposed or thinly-covered "abovegrade" ${ }^{3}$ piles resulting from earlier operations. Breslin and Glauberman (1970) have shown dramatic photographs of "dust devils" moving across such exposed tailings piles. Recent studies on bare, inactive tailings piles in western New Mexico (Dreesen, 1978) have demonstrated that large quantities of tailings sands may be caried downwind by particle creep and saltation, particularly during strong spring winds. Windblown tailings from inactive, unstabilized tailings piles in the Western States are responsible for dose rates greater than $25 \mathrm{mRem} / \mathrm{yr}$ (millirem per year) ${ }^{4}$ at distances up to 1 mile from the pile (U.S. Environmental Protection Agency, 1976b). Under present NRC mill licensing criteria, applicants must have a program that minimizes the dispersal of airborne particulates from tailings disposal areas during mill operations and in the interim period prior to reclamation. Control measures generally include keeping the tailings moist and (or) using chemical binding agents (Martin, 1978; U.S. Nuclear Regulatory Commission, 1978e).

\section{SURFACE WATER TRANSPORT AND LEACHING}

First awareness of the environmental problems associated with uranium mill tailings

\footnotetext{
"In this report, "above grade" and "below grade" refer to NRC terminology (U.S. Nuclear Regulatory Commission, 1979a) and indicate positions above or below the surrounding land surface. Other meanings associated with the term "grade" (see Gary and others, 1972 , p. 305) are not implied.
}

came in the late 1950's with the finding of high levels of soluble and suspended radium-226 in reaches of rivers in the Colorado River basin downstream from uranium mills. Prior to this time, one of the mills in the area discharged waste solutions and tailings to a neighboring water course. Photographs from the 1950's and 1960 's of several of the mill sites (Sigler and others, 1966) show the proximity of the unstabilized tailings piles to the banks of major rivers in the area. Such tailings are very susceptible to soil erosion processes and downstream transport in the watershed. Laboratory (see table 2) and field studies (Tsivoglou and others, 1960; Havlik and others, 1968b) suggest that uranium mill tailings and radiumcontaminated river sediments occurring in streambeds can act as sources of dissolved radium to the flowing water. Corrective action to eliminate the discharge of liquid and solid mill effluents to the river were taken in 1959 (see page 8). Efforts at controlling erosion of the piles, begun in the late 1960's under the regulatory authority of the Colorado Department of Health, will undoubtedly be addressed by the remedial action program mandated by the Uranium Mill Tailings Radiation Control Act of 1978. The siting of tailings disposal areas on streambanks would not be permitted under present licensing criteria for uranium mill tailings management (U.S. Nuclear Regulatory Commission, 1977a). Nevertheless, the leaching of tailings by surface waters should be considered as the potential result of longterm erosional processes.

\footnotetext{
${ }^{4}$ For a discussion of ionizing radiation exposure, dose, and dose equivalent measurements, see Shapiro (1972) or other health physics texts. The mean annual whole body background radiation doses from natural sources of external ionizing radiation in Albuquerque, N. Mex.; Grand Junction, Colo.; and Cheyenne, Wyo., are about 132, 159, and 164 millirads respectively (Eisenbud, 1963). The maximum permissible organ (excluding the thyroid) or whole body dose equivalent for persons in the general public as the result of exposures to planned discharges of radioactive materials to the general environment from uranium fuel cycle activities, and to radiation from these operations, will be $25 \mathrm{mRem} / \mathrm{yr}(0.025 \mathrm{Rem} /$ yr). Th:s standard (effective date for operations associated with milling of uranium ore is December 1, 1980), however, excludes dose equivalents attributable to radon and its daughter products (U.S. Environmental Protection Agency, 1976a, p. A17-A18; Federal Register, v. 42, no. 9, January 13, 1977, Part VII, p. 28582861). While the standard excludes operations at waste disposal sites, windblown tailings at activity licensed millng sites are considered. The standard, however, does not apply retroactively to offsite, windblown tailings. At the inactive mill sites, remedial action to correct such ground contamination will likely be part of the program initiated under the Uranium Mill Tailings Radiation Control Act of 1978 .
} 
In the past, there have been tailings dike failures, and essentially instantaneous releases of up to 15,000 tons of tailings from an impoundment area (U.S. Atomic Energy Commission, 1974). Present design, construction and inspection criteria for earth and rockfill embankments used for retaining tailings at newly-licensed uranium mills using aboveground impoundments (U.S. Nuclear Regulatory Commission, $1977 \mathrm{~b}$ ) should reduce the probability of such failures.

\section{EXTERNAL GAMMA RADIATION}

Primarily because of gamma radiation emited by bismuth-214 (see fig. 2, p. 5), a uranium mill tailings pile constitutes a source for external radiation exposure. The exposure rate at the surface of an uncovered tailings pile may be estimated by the relationship developed by Schiager (1974) as follows:

$$
X=2.4 C_{\mathrm{Ra}}
$$

where

$X=$ exposure rate at the surface of the pile, in microroentgens per hour, and

$C_{\mathrm{Ra}}=$ concentration of radium-226 in the tailings in picocuries per gram.

Thus for an exposed tailings pile containing $560 \mathrm{pCi}$ of radium $-226 / \mathrm{g}$, the gamma exposure rate at the surface is estimated to be about $1,340 \mu \mathrm{R} / \mathrm{hr}$, or about $12 \mathrm{R} / \mathrm{yr}$.

\section{CONTAMINATION OF TERRESTRIAL AND AQUATIC VEGETATION}

Vegetation growing atop or adjacent to a uranium mill tailings disposal area may exhibit elevated levels of contaminants such as radium-226 as a result of either root uptake and translocation or surficial contamination of foliage by airborne particulates (Moffett and Tellier, 1977 ; Dreesen and others, 1978; Kelley, 1978; Whicker, 1978). Thick soil covers will mitigate both pathways. However, many plants, especially selected species native to arid zones are deep-rooted, and may penetrate the underlying tailings (Kelley, 1978; Whicker, 1978; Wullstein, 1978). Researchers, sponsored by the U.S. Department of Energy, are examining the uptake of radionuclides by plant species that may be involved in the vegetative stabilization of uranium mill tailings (written commun., R. H. Kennedy, 1979). Translocation of radium, or perhaps radon (Hendricks, 1977), to foliage may result in enhanced radon exhalation from buried tailings. Ingestion of contaminated vegetation by humans, either directly or by consumption of livestock or game animals, which have grazed upon such vegetation, represents a potential source of human radiation exposure.

Water quality studies on the Animas River in the vicinity of the now inactive uranium mill in Durango, Colo., by the U.S. Public Health Service and Utah State University in the late 1950's and early 1960's showed that aquatic algae may be radium accumulators. In 1958, essentially all of the liquid wastes from the mill were discharged to the river along with about 13.6 metric tons/day (15 tons/day) of solid tailings (Tsivoglou and others, 1960). Early in 1959, impoundment and treatment of liquid effluents from the mill began and radium levels in the river water were observed to decine (Sigler and others, 1966). The mill closed in 1963 (Ford, Bacon, and Davis Utah, Inc., 1977; GJT-6). A 1958 sampling of the aquatic biota in the river by the U.S. Public Health Service at locations 2, 23, and 59 river-miles below the mill showed radium-226 concentrations in the algae to be about 80, 30, and 5 times greater, respectively, than the concentrations observed in algae collected 1 mile upstream of the mill. The highest algal concentration of radium-226 observed was apparently $880 \mathrm{pCi} / \mathrm{g}$ (ashed weight), measured in the spring of 1959 . This compares with radium levels in algae sampled upstream of the mill of about 3 to $6 \mathrm{pCi} / \mathrm{g}$. With the initiation of pollution control measures at the mill, radium levels in the river water declined, and radium-226 concentrations in algae sampled in the downstream zone during 1960-1963 averaged about 2 to 4 times that of the upstream samples (Sigler and others, 1963). Pilot studies are underway at one location in the Grants Mineral Belt of New Mexico on the use of algal uptake of radium as a pollution control measure for uranium mine and mill effluents (Eadie and Kaufmann, 1977). The uptake by algae of radium-226 entering surface waters can eventually also lead to incorporation into the human food chain. 


\section{SEEPAGE}

The movement of both mill effluents through active tailings ponds and precipitation through inactive piles creates the potential for groundwater contamination. Some of the environmental, ore, and process factors that may influence the migration of radionuclides and other potentially toxic elements through the soil and subsurface materials are outlined as follows.

\section{Environmental Factors}

The arid and semi-arid climate in the Western States where most of the active and inactive mills in the United States are situated mitigates against extensive leaching of the tailings by percolating rainwater. At the model mill considered in the generic environmental impact statement on uranium milling. (U.S. Nuclear Regulatory Commission, 1979a), the long-term rate at which water would seep through the tailings into the subsoil, following the cessation of mill operations and the accompanying discharge of waste solutions to the tailings pond, is estimated to be 5 percent of the rate of seepage during the period of operation. There are, however, uranium deposits and (or) mills located in areas of the Nation which have greater annual precipitation such as the Texas Gulf Coastal Plain and southeastern Alaska (Reed and others, 1976). Also, over the course of geologic time, a future shift to pluvial ${ }^{5}$ conditions in the now arid Western States is certainly a possibility. For example, the present-day Chihuahuan, Sonoran, and Mohave Deserts of the Southwestern United States were woodlands less than 10,000 years ago, indicating a period of higher rainfall (Van Devender, 1977), or of lower temperature accompanied by lower evaporation rates (Brakenridge, 1978).

The rate of movement of a dissolved species through a porous medium is a function of the relative affinity of the solute for the solution phase, as compared to the solid phase, as well as the bulk velocity of the fluid. Thus, the permeability and sorptive properties of the soil and rock underlying the disposal zone, and the $\mathrm{pH}, \mathrm{Eh}$, ionic strength, and composition of the

\footnotetext{
5 "Pluvial" refers to an episode of time or climate, especially one corresponding to a glacial age, characterized by abundant rainfall.
}

ground water influences the rate of subsurface transport of radionuclides. Factors influencing the mobilization or retardation of specific nuclides are discussed in the leaching section below.

Lining of the tailings ponds with low permeability materials may inhibit the movement of radionuclides into the ground water. These materials may be chemically-inert, synthetic polymers such as polyvinyl chloride whose retarding effect is purely physical, or surfaceactive, natural materials such as bentonite, which may limit the movement of radionuclides by chemical as well as physical means. The use of liners is becoming more common at newly-licensed mills in the United States, in response to NRC guidelines (U.S. Nuclear Regulatory Commission, 1977a) calling for minimization of seepage of toxic materials from tailings disposal areas into the ground-water system. At the Madawaska mill site near Bancroft, Ontario, a slurry of bentonite, local clay, and cement was injected into the alluvium to the bedrock surface through slotted pipes in an attempt to form a "grout curtain" to reduce the amount of radium-226 and other contaminants, seeping from a tailings pond, that will reach a nearby lake (Dodds and others, 1978).

When mill operations cease and waste solutions are no longer pumped to the tailings retention ponds, the liquid will eventually evaporate, leaving a pile of sand, slime, neutralization and $\mathrm{BaSO}_{4}$ sludges, and process reagents. The recharge to local ground-water systems from the tailings retention system will be less after milling operations end than during operations owing to the cessation of input of process effluents. In the presently arid and semi-arid zones of the United States where most of the mill tailings are located, ground-water recharge by precipitation is low, thereby restricting the movement of radionuclides.

Digital modeling studies of water movement in uncovered, inactive uranium mill tailings profiles suggest that under precipitation and evaporation conditions occurring in north-central Utah, long-term recharge to underlying shallow (water table at about $3 \mathrm{~m}$ ) ground water can, however, occur (Hendricks, 1978; Klute and Heermann, 1978). Cover materials, vegetation, profile layering, intensity, duration, 
and character of evaporation and precipitation (rain and snow) events, and depth to the ground-water table may influence water flow in the profile and the extent of recharge (Klute and Heermann, 1978). These early results, however, suggest that tailing management schemes, which rely on the maintenance of moist conditions in cover materials and near-surface tailings to provide for radon-flux attenuation (Argonne National Laboratory, 1978) should be evaluated in light of the potential for increased recharge (Hendricks, 1978). In uranium mining and milling areas with relatively high rainfall, for example, the Elliot Lake area of Ontario, Canada, such recharge through the tailings may be appreciable even after mill operations cease.

\section{Ore Factors}

The mineralogy of the host rock will influence the chemical properties of the water percolating through a tailings pile. The oxidation of pyrite contained in uranium mill tailings may result in the production of sulfuric acid. Some Canadian uranium ores contain from 4 to 8 percent pyrite, and the inactive tailings piles at Elliot Lake, Ontario, exhibit $\mathrm{pH}$ values of 1.9 to 2.3 (Watkin and Winch, 1973; Moffett, 1976). As thorium is soluble under acid leaching conditions (see below), seepage from an inactive tailings pile at Elliot Lake containing only $12 \mathrm{pCi}$ of radium-226/L, had $7,500 \mathrm{pCi}$ of thorium-230/L and $1,800 \mathrm{pCi}$ of thorium232/L (Moffett, 1976). Uranium ores mined in the United States generally have lower pyrite contents. The Ambrosia Lake, New Mexico (Bell, 1963; Hilpert, 1969), Saguache County, Colorado (U.S. Forest Service, 1978), and Shirley Basin, Wyo., (Harshman, 1972), deposits contain significant amounts of pyrite, the latter containing about 1 percent pyrite in the unaltered sandstone host rock and from about 0.2 to 18 percent pyrite in the ore.

\section{Process Factors}

The leaching solution, alkali or acid, will influence the chemical form, carbonates or sulfates, of the radionuclides in the tailings, and the $\mathrm{pH}$ of the tailings. At the Tuba City, Ariz., uranium mill site, the inactive acid-leached tailings piles have a $\mathrm{pH}$ as low as 2.3, while the inactive alkali-leached tailings piles have a pH as high as 9.5 (Havens and Dean, 1969).

The neutralization of acidic mill effluents with lime and (or) limestone to about $\mathrm{pH} 8$ will precipitate most soluble thorium-230 and lead-210 as hydroxide and (or) carbonate phases, and reduce soluble radium-226 levels from about $1,000 \mathrm{pCi} / \mathrm{L}$ to about $100 \mathrm{pCi} / \mathrm{L}$. The dissolved Ra-226 concentration in the neutralized effluent may subsequently be reduced to about $3 \mathrm{pCi} / \mathrm{L}$ by the coprecipitation of radium with $\mathrm{BaSO}_{4}$ following the addition (to the neutralized, settled effluent) of $\mathrm{BaCl}_{2}$ in the presence of excess sulfate (International Atomic Energy Agency, 1976). Such procedures remove radionuclides from the liquid phase and transfer them to a solid phase where they are less likely to be environmentally mobile.

\section{USE OF TAILINGS AS A CONSTRUGTION MATERIAL}

Before the radiological hazards associated with uranium mill tailings were recognized, the desirable mechanical properties of the tailings sands, and the low cost of the material to local contractors, encouraged its use as a fill material in construction projects. The radiological hazards to occupants of structures constructed using these tailings sands involve:

- External radiation exposure associated with gamma-emitting radionuclides in the tailings.

- Inhalation of radon daughter products, and the resultant radiation dose to lung tissue.

An estimated 300,000 tons of tailings were used in the Grand Junction area of Colorado, with about 50,000 tons of this going into home, business, and school construction, such as bedding for concrete slabs, water lines, and sewer lines. The use of tailings at Grand Junction continued from 1952 to 1966 when work by the Colorado State Department of Health and the U.S. Public Health Service showed elevated radiation levels in structures where tailings had been used. In 1972, a remedial action program (now about half completed) aimed at about 700 such structures, and involving tailings removal and backfill with uncontaminated material, was begun under the management of the Colorado State Department of Health and the U.S. 
Department of Energy (Hendricks, 1977; Comptroller General of the United States, 1978).

While the Grand Junction case appears to have been the most extensive, and has been the subject of the most documentation and public attention, the use of uranium mill tailings for construction purposes has apparently occurred to a limited extent in other communities where nearby piles existed, including Salt Lake City, Utah (Ford, Bacon, and Davis Utah, Inc., 1978, table 1-1). In the Cane Valley area of southeastern Utah and northeastern Arizona, uranium mill tailings and ore had been used through 1975 for the construction of about 16 residential structures on the Navajo Reservation. These materials were incorporated directly into the floor, foundation materials, and exterior stucco, in contrast to their usage at Grand Junction, primarily as bedding material for floors and foundations (Hans and Douglas, 1975). The 1975 U.S. Environmental Protection Agency study which documented this practice at Cane Valley has presumably resulted in its cessation, and the remedial action and control measures at inactive and active mills mandated by the Uranium Mill Tailings Radiation Control Act of 1978 is likely to further curtail the use of tailings as a contruction material in the near future.

\section{LEACHING BEHAVIOR OF RADIUM, THORIUM, AND URANIUM}

\section{RADIUM}

Radium exhibits only the $\left(2^{+}\right)$oxidation state in solution, and its chemistry resembles that of barium. Radium forms water-soluble chloride, bromide, and nitrate salts. The phosphate, carbonate, selenate, fluoride, and oxalate salts of radium are slightly soluble in water, while radium sulfate is relatively insoluble in water $\left[K_{\mathrm{sp}}=4.25 \times 10^{-11}\right.$ at $20^{\circ} \mathrm{C}$ (Sedlet, 1966) ]. This solubility product for $\mathrm{RaSO}_{4}$, the presumed chemical form of radium in sulfuric acid-leached tailings, corresponds to a radium concentration of $1.5 \times 10^{-3} \mathrm{~g} / \mathrm{L}$ of pure water, and of $4.6 \times 10^{-6} \mathrm{~g} / \mathrm{L}$ of water containing 200 ppm sulfate. The latter concentration of radium, while only a few parts-per-billion, is still about six orders of magnitude greater than that permitted in drinking water (table 1).
The hydrated ion of radium is the smallest in the alkaline earth series, and hence it would tend to be preferentially retained by ion exchange surfaces (Kirby and Salutsky, 1964; Sedlet, 1966). Radium has the least tendency of all the alkaline earths to form complex ions. Like the other alkaline earths, radium forms few complexes in acidic solutions. In alkaline solutions, anionic complexes of radium with organic ligands, such as EDTA (ethylenediamine tetraacetic acid) and citric acid, are known to occur (Sedlet, 1966). Means and others (1978) suggest that EDTA-mobilization may be responsible for apparently elevated levels of radium seen in water and soil sampled around a radioactive waste disposal trench at the Oak Ridge National Laboratory burial ground. The possible complexation by natural chelating agents, such as fulvic acid, has apparently not been studied. Complexes with inorganic ligands, such as bicarbonate or chloride, are not reported to occur. Radium compounds have low solubilities in organic solvents (Kirby and Salutsky, 1964).

Radium apparently does not form discrete minerals, but can coprecipitate with tannin and gelatin (Vdovenko and Dubasov, 1975), calcium carbonate, hydrous ferric oxides (Tanner, $1964 \mathrm{~b})$, barite $\left(\mathrm{BaSO}_{4}\right)$, celestite $\left(\mathrm{SrSO}_{4}\right)$ and angelsite $\left(\mathrm{PbSO}_{4}\right)$ (Austin and Droullard, 1978), tricalcium phosphate, thorium oxalate, and phosphate (Sedlet, 1966), and aluminum phosphate (Koide and Bruland, 1975). Associations of radium with barium sulfate are known in uranium ore deposits (Granger and others, 1961) and in nodules in cattle thyroids (Middlesworth, 1978). These associations may be due either to coprecipitation or the adsorption of radium onto existing barium sulfate crystals. Tanner (1964) cites Russian workers who report radium not to coprecipitate with gypsum $\left[\mathrm{CaSO}_{4} \cdot 2 \mathrm{H}_{2} \mathrm{O}\right]$. However, by-product gypsum from phosphoric acid production in central Florida contains about 20 to $30 \mathrm{pCi} / \mathrm{g}$ of radium-226 (Kaufmann and Bliss, 1977). Radium may be sorbed by clay minerals, colloidal silicic acid (Vdovenko and Dubasov, 1975), manganese oxides (Moore and Reid, 1973), and organic matter (Titayeva, 1967; Morse, 1970; Titayeva and others, 1977). Ground waters dominated by chloride and (or) 
bicarbonate, low in sulfate, with high ionic strengths and high contents of calcium and barium are conducive to the transport of radium (Tanner, 1964b; Kagan, 1967 ; Perel'man, 1972; Cadigan and others, 1976; Felmlee and Cadigan, 1978a). While, unlike uranium, only a single valence state exists for radium, the influence of oxidation-reduction conditions on the mobility of elements, such as iron, manganese, and sulfur, which may be involved in the coprecipitation and sorption of radium should be considered.

In table 2, the results of several studies on the leachability of radium from uranium ores and mill tailings are listed. These data suggest the following generalizations:

- Radium in uranium ore is only slightly soluble in $\mathrm{H}_{2} \mathrm{SO}_{4}$, but highly soluble in $\mathrm{HCl}$ and $\mathrm{HNO}_{3}$, presumably because of the greater solubility of $\mathrm{RaCl}_{2}$ and $\mathrm{Ra}\left(\mathrm{NO}_{3}\right)_{2}$ as compared to $\mathrm{RaSO}_{4}$.

- Radium in acid-processed tailings is leachable with EDTA, $\mathrm{HCl}, \mathrm{HNO}_{3}$ and distilled water. The solubility in distilled water is highly dependent upon the liquid-to-solid ratio used in the test, suggesting a limiting solubility product or suspension $\mathrm{pH}$ effect. The water leaching data presented in table 2 suggest that uranium mill tailings in the environment may constitute a longterm source for radium contamination of contacting surface and ground waters. Indeed some tailings in Canada that have been exposed to weathering forces for several years apparently do show evidence of radium depletion (Moffett and Tellier, 1977; Skeaff, 1977).

- The data on salt extraction (table 2) confuse, as well as clarify, the picture of how radium exists in the tailings. The differences in tailings materials and leaching conditions (time, temperature, solute concentrations ,solid-solution ratio) makes a comparison of the extraction-yield data difficult, as is an extrapolation of these data to natural environments. There are many apparent contradictions; most notable is the effect of barium chloride leaching on radium removal. The recent work of Seeley (1976) on radium removal from real and simulated acid-leached uranium mill tail- ings slimes suggests that both adsorption and coprecipitation reactions may be involved in the retention of radium by the tailings. Radium may be sorbed on active sites of silicate minerals, as well as coprecipitated with several alkaline earth sulfate compounds of widely differing solubilities, for example, $\mathrm{CaSO}_{4}, \mathrm{SrSO}_{4}$, and $\mathrm{BaSO}_{4}$. Hence, radium release from the tailings probably involves both surface desorption mechanisms, as well as multicomponent solubility considerations. By analogy to Seeleys work on acid leached tailings, alkaline earth carbonates are probably involved in the immobilization of radium in alkaline-leached uranium mill tailings.

Shearer and Lee (1964) suggest that in acid-leached uranium mill tailings, radium exists as a coprecipitate with barium sulfate. Work by Levins and others (1978) on the leaching of alkaline earth elements from Australian-ore uranium mill tailings with varying strengths of sodium chloride solution showed a parallel increase in barium and radium-226 concentration in the leachate with increasing salt molarity, while calcium and strontium concentrations in the leachate varied little with salt molarity, thereby supporting an association of radium with a barium phase. However, other investigatons (Seeley, 1976; Ryon and others, 1977; Kaiman, 1977,1978 ) suggest that radium may show more association with the far more soluble calcium sulfate mineral, gypsum. Also, a member of the jarosite family, a group of hydrous iron sulfate minerals, containing $80,000 \mathrm{pCi} / \mathrm{g}$ of radium-226 has been found in weathering pyritic tailings from Elliot Lake, Ontario (Moffett and others, 1977). This jarosite-material may have precipitated during the acid-leaching process as suggested by Kaiman (1977, 1978), or may have been formed during the weathering of the ore or the tailings. The latter mechanism is suggested by the work of Ivarson and others (1978) on the synthesis of jarosite $\left[\mathrm{KFe}_{3}\left(\mathrm{SO}_{4}\right)_{2}(\mathrm{OH})_{6}\right]$ in the presence of glauconite, illite, and microcline, and natrojarosite $\left[\mathrm{NaFe}_{3}\left(\mathrm{SO}_{4}\right)_{2}(\mathrm{OH})_{6}\right]$ in 
TABLE 2.-Proportion of radium-226 leached from uranium ore, uranium mill tailings, and river bottom sediments in laboratory tests

\begin{tabular}{|c|c|c|c|}
\hline Material & Leaching conditions & $\begin{array}{c}\text { Proportion of of } \\
\text { Ra-226 } \\
\text { extracted } \\
\text { (in percent) }\end{array}$ & Reference \\
\hline \multirow[t]{13}{*}{$\begin{array}{l}\text { Uranium } \\
\text { ore. }\end{array}$} & $\begin{array}{l}\text { Distilled water, } 25^{\circ} \mathrm{C}, 1 \text { percent solids, } \\
65 \text { min. }\end{array}$ & 0.42 & Shearer, 1962 (table 17). \\
\hline & $\begin{array}{l}\text { Distilled water, room temperature, } 10 \text { percent } \\
\text { solids, } 3 \mathrm{hr} \text {. }\end{array}$ & $2.3-2.7$ & Havlik and others, $1968 \mathrm{~b}$. \\
\hline & $\begin{array}{l}1 N \mathrm{KCl} \text {, room temperature, } 10 \text { percent solids, } \\
0.25-5.0 \mathrm{hr} \text {. }\end{array}$ & $22 \quad-31$ & Havlik and others, $1968 \mathrm{~b}$. \\
\hline & $\begin{array}{l}0.01 \mathrm{~N} \mathrm{KCl} \text {, room temperature, } 10 \text { percent } \\
\text { solids, } 0.25 \mathrm{hr} \text {. }\end{array}$ & $2.6-9$ & Havlik and others, $1968 \mathrm{~b}$. \\
\hline & $\begin{array}{l}1 N \mathrm{NaCl} \text {, room temperature, } 10 \text { percent } \\
\text { solids, } 0.25-5 \mathrm{hr} \text {. }\end{array}$ & $\begin{array}{ll}14 & -17\end{array}$ & Havlik and others, $1968 \mathrm{~b}$. \\
\hline & $\begin{array}{l}1 \mathrm{~N} \mathrm{CaCl}_{2} \text {, room temperature, } 10 \text { percent solids, } \\
1-5 \mathrm{hr} \text {. }\end{array}$ & $3.1-5.3$ & Havlik and others, $1968 \mathrm{~b}$. \\
\hline & $\begin{array}{l}1 \mathrm{~N} \mathrm{BaCl} \text {, room temperature, } 10 \text { percent solids, } \\
0.25 \mathrm{hr} \text {. }\end{array}$ & $0.1-0.3$ & Havlik and others, $1968 \mathrm{~b}$. \\
\hline & $\begin{array}{l}\text { Na-carbonate/bicarbonate, in-mill alkaline- } \\
\text { leaching conditions. }\end{array}$ & $1.5-2.2$ & Moffett, 1976. \\
\hline & $\mathrm{H}_{2} \mathrm{SO}_{4}$, in-mill leaching acid conditions & $0.4-0.7$ & Moffett, 1976. \\
\hline & $0.1 N \mathrm{HCl}$, room temperature, $5-8 \mathrm{hr}$ & $2.9-4.5$ & Havlik and others, 1968a. \\
\hline & $1.5 M \mathrm{HCl}, 60^{\circ} \mathrm{C}, 25$ percent solids, $3 \times 30 \mathrm{~min}$ & $86-98$ & $\begin{array}{l}\text { Borrowman and Brooks, } \\
1975 .\end{array}$ \\
\hline & $3 M, \mathrm{HCl}, 85^{\circ} \mathrm{C}, 25$ percent solids, $1 \mathrm{hr}$ & 90 & Seeley, 1976. \\
\hline & $3 M \mathrm{HNO}_{3}, 85^{\circ} \mathrm{C}, 25$ percent solids, $1 \mathrm{hr}$ & 94 & Seeley, 1976. \\
\hline \multirow{14}{*}{$\begin{array}{l}\text { Acid-leached } \\
\text { uranium } \\
\text { mill tail- } \\
\text { ings. }\end{array}$} & $\begin{array}{l}\text { Distilled water, } 25^{\circ} \mathrm{C}, 3 \text { percent solids, } 15- \\
90 \mathrm{hr} \text {. }\end{array}$ & $0.2-1.0$ & Ryon and others, 1977. \\
\hline & $\begin{array}{l}\text { Distilled water, } 25^{\circ} \mathrm{C}, 3 \text { percent solids, } 380 \\
\mathrm{hr}, 10 \text { successive leaches of } 15-90 \mathrm{hr} \text { each. }\end{array}$ & 4.4 & Ryon and others, 1977. \\
\hline & Distilled water, $25^{\circ} \mathrm{C}, 1$ percent solids, $1 \mathrm{hr}$ & 1.2 & Shearer, 1962 (table 20). \\
\hline & Distilled water, $25^{\circ} \mathrm{C}, 0.1$ percent solids, $1 \mathrm{hr}$ & 23.2 & Shearer, 1962 (table 20). \\
\hline & $\begin{array}{l}\text { Distilled water, } 25^{\circ} \mathrm{C}, 0.01 \text { percent solids, } \\
1 \mathrm{hr} \text {. }\end{array}$ & 40 & Shearer, 1962 (table 20). \\
\hline & $\begin{array}{l}\text { Distilled water, room temperature, } 10 \text { percent } \\
\text { solids, } 5-15 \mathrm{hrs} \text {. }\end{array}$ & $3.5-4.7$ & $\begin{array}{l}\text { Havlik and others, } \\
\text { 1968a, b. }\end{array}$ \\
\hline & $\begin{array}{l}1 N \mathrm{KCl} \text {, room temperature, } 10 \text { percent solids, } \\
1 \mathrm{hr} \text {. }\end{array}$ & 100 & Havlik and others, $1968 \mathrm{~b}$. \\
\hline & $\begin{array}{l}1 \mathrm{~N} \mathrm{~K}_{3} \mathrm{PO}_{4} \text {, room temperature, } 10 \text { percent solids, } \\
6 \mathrm{hr} \text {. }\end{array}$ & 2.4 & Havlik and others, $1968 \mathrm{~b}$. \\
\hline & $\begin{array}{l}0.1 \mathrm{~N} \mathrm{KCl} \text {, room temperature, } 10 \text { percent solids, } \\
1 \mathrm{hr} \text {. }\end{array}$ & 54 & Havlik and others, $1968 \mathrm{~b}$. \\
\hline & $\begin{array}{l}0.01 \mathrm{~N} \mathrm{KCl} \text {, room temperature, } 10 \text { percent } \\
\text { solids } 15 \text { min. }\end{array}$ & 10 & Havlik and others, $1968 \mathrm{~b}$. \\
\hline & $\begin{array}{l}1 N \mathrm{NaCl}, \text { room temperature, } 10 \text { percent } \\
\text { solids, } 6 \mathrm{hr} \text {. }\end{array}$ & 95 & Havlik and others, $1968 \mathrm{~b}$. \\
\hline & $\begin{array}{l}1 N \mathrm{Na}_{3} \mathrm{PO}_{4} \text {, room temperature, } 10 \text { percent } \\
\text { solids, } 6 \mathrm{hr} \text {. }\end{array}$ & 6.6 & Havlik and others, $1968 \mathrm{~b}$. \\
\hline & $\begin{array}{l}1 \mathrm{~N}\left(\mathrm{NH}_{4}\right)_{2} \mathrm{SO}_{4} \text {, room temperature, } 10 \text { percent } \\
\text { solids, } 1 \mathrm{hr} \text {. }\end{array}$ & 12 & Havlik and others, $1968 \mathrm{~b}$. \\
\hline & $\begin{array}{l}1 \mathrm{~N} \mathrm{CaCl}_{2} \text {, room temperature, } 10 \text { percent solids, } \\
3 \mathrm{hr} \text {. }\end{array}$ & 48 & Havlik and others, $1968 \mathrm{~b}$. \\
\hline
\end{tabular}


TABLE 2.-Proportion of radium-226 leached from uranium ore, uranium mill tailings, and river bottom sediments in laboratory tests-Continued

\begin{tabular}{|c|c|c|c|}
\hline Material & Leaching conditions & $\begin{array}{l}\text { Proportion of } \\
\text { Ra-226 } \\
\text { extracted } \\
\text { (in percent) }\end{array}$ & Reference \\
\hline \multirow{11}{*}{$\begin{array}{l}\text { Acid-leached } \\
\text { uranium } \\
\text { mill tail- } \\
\text { ings. }\end{array}$} & 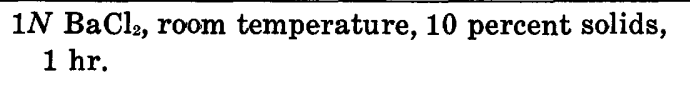 & 0.9 & Havlik and others, $1968 \mathrm{~b}$. \\
\hline & $0.01 \mathrm{M}, \mathrm{BaCl}_{2}, 25^{\circ} \mathrm{C}, 1$ percent solids, $1 \mathrm{hr}$ & $\begin{array}{ll}35 & -37\end{array}$ & Shearer, 1962 (table 29). \\
\hline & $\begin{array}{l}1 N \mathrm{MgCl}_{2} \text {, room temperature, } 10 \text { percent solids, } \\
5 \mathrm{hr} \text {. }\end{array}$ & 9.3 & Shearer, 1962 (table 29). \\
\hline & $\begin{array}{l}1 N \mathrm{MgCO}_{3} \text {, room temperature, } 10 \text { percent } \\
\text { solids, } 5 \mathrm{hr} .\end{array}$ & 2.0 & Shearer, 1962 (table 29). \\
\hline & $0.15 M$ EDTA, $60^{\circ} \mathrm{C}, 15$ percent solids, $5 \mathrm{hr}$ & 80 & $\begin{array}{l}\text { Borrowman and Brooks, } \\
1975 .\end{array}$ \\
\hline & $1.5 M \mathrm{HCl}, 60^{\circ} \mathrm{C}, 25$ percent solids, $3 \times 30 \mathrm{~min}_{-}$ & 92 & $\begin{array}{l}\text { Borrowman and Brooks, } \\
1975 .\end{array}$ \\
\hline & $\begin{array}{l}0.1 \mathrm{~N} \mathrm{HCl} \text {, room temperature, } 10 \text { percent } \\
\text { solids, } 0.25-5 \mathrm{hr} \text {. }\end{array}$ & 22.4 & Havlik and others, 1968a. \\
\hline & $\begin{array}{l}0.001 \mathrm{~N} \mathrm{HCl} \text {, room temperature, } 10 \text { percent } \\
\text { solids, } 0.25-5 \mathrm{hr} \text {. }\end{array}$ & 9.6 & Havlik and others, 1968a. \\
\hline & $\begin{array}{l}10^{-6} \mathrm{~N} \mathrm{H}_{3} \mathrm{BO}_{4}(\mathrm{pH} 6) \text {, room temperature, } 10 \\
\text { percent solids, } 0.25-5 \mathrm{hr} .\end{array}$ & 5.0 & Havlik and others, 1968a. \\
\hline & $\begin{array}{l}10^{-5} \mathrm{M} \mathrm{NaHCO} \text { ( } \mathrm{pH} \mathrm{9)}, \text { room temperature, } 10 \\
\text { percent solids. }\end{array}$ & 2.8 & Havlik and others, 1968. \\
\hline & $\begin{array}{l}0.1 \mathrm{~N} \mathrm{NaOH} \text {, room temperature, } 10 \text { percent } \\
\text { solids, } 0.25-5 \mathrm{hr} \text {. }\end{array}$ & 4.9 & Havlik and others, $1968 \mathrm{a}$. \\
\hline $\begin{array}{l}\text { Acid-leached } \\
\text { uranium } \\
\text { mill tailings } \\
\text { (sand frac- } \\
\text { tion only). }\end{array}$ & $3 M \mathrm{HNO}_{3}, 85^{\circ} \mathrm{C}, 25$ percent solids, $1 \mathrm{hr}$ & 94 & Seeley, 1976. \\
\hline \multirow{12}{*}{$\begin{array}{l}\text { Acid-leached } \\
\text { uranium } \\
\text { mill tailings } \\
\text { (slime frac- } \\
\text { tion only). }\end{array}$} & $3 M \mathrm{HNO}_{3} 85^{\circ} \mathrm{C}, 25$ percent solids, $1 \mathrm{hr}$ & 72 & Seeley, 1976. \\
\hline & $\begin{array}{l}\mathrm{H}_{2} \mathrm{O} \text {, room temperature, } 3 \text { percent solids, } \\
\quad 16 \mathrm{hr} \text {. }\end{array}$ & 11 & Seeley, 1976. \\
\hline & $\begin{array}{l}\mathrm{H}_{2} \mathrm{O} \text {, room temperature, } 0.01 \text { percent solids, } \\
15 \text { min (in cyclosizer, wet particle size } \\
\text { analyzer). }\end{array}$ & $20-54$ & Skeaff, 1977. \\
\hline & $\begin{array}{l}1 M \mathrm{LiCl} \text {, room temperature, } 3 \text { percent solids, } \\
16 \mathrm{hr} \text {. }\end{array}$ & 11 & Seeley, 1976. \\
\hline & $\begin{array}{l}1 M \mathrm{KCl} \text {, room temperature, } 3 \text { percent solids, } \\
16 \mathrm{hr} \text {. }\end{array}$ & 12 & Seeley, 1976 \\
\hline & $\begin{array}{l}1 M \mathrm{NH}_{4} \mathrm{Cl} \text {, room temperature, } 3 \text { percent solids, } \\
16 \mathrm{hr} \text {. }\end{array}$ & 15 & Seeley, 1976. \\
\hline & $\begin{array}{l}1 M \mathrm{AlCl}_{3}, \text { room temperature, } 3 \text { percent solids, } \\
16 \mathrm{hr} \text {. }\end{array}$ & 20 & Seeley, 1976. \\
\hline & $\begin{array}{l}1 M \mathrm{HCl} \text {, room temperature, } 3 \text { percent solids, } \\
16 \mathrm{hr} \text {. }\end{array}$ & 34 & Seeley, 1976. \\
\hline & $\begin{array}{l}1 M \mathrm{NaCl}, \text { room temperature, } 3 \text { percent solids, } \\
16 \mathrm{hr} \text {. }\end{array}$ & 36 & Seeley, 1976. \\
\hline & $\begin{array}{l}1 M \mathrm{FeCl}_{3}, \text { room temperature, } 3 \text { percent solids, } \\
16 \mathrm{hr} \text {. }\end{array}$ & 59 & Seeley, 1976. \\
\hline & $\begin{array}{l}1 M \mathrm{BaCl}_{2} \text {, room temperature, } 3 \text { percent solids, } \\
16 \mathrm{hr} \text {. }\end{array}$ & 65 & Seeley, 1976. \\
\hline & $\begin{array}{l}1 M \mathrm{CaCl}_{2} \text {, room temperature, } 3 \text { percent solids, } \\
\quad 16 \mathrm{hr} \text {. }\end{array}$ & 73 & Seeley, 1976. \\
\hline
\end{tabular}


TABLE 2.-Proportion of radium-226 leached from uranium ore, uranium mill tailings, and river bottom sediments in laboratory tests-Continued

\begin{tabular}{|c|c|c|c|}
\hline Material & Leaching conditions & $\begin{array}{c}\text { Proportion of } \\
\text { Ra-226 } \\
\text { extracted } \\
\text { (in percent) }\end{array}$ & Reference \\
\hline \multirow{2}{*}{$\begin{array}{l}\text { Acid-leached } \\
\text { uranium mill } \\
\text { tailings. } \\
\text { (Slime frac- } \\
\text { tion only.) }\end{array}$} & $\begin{array}{l}1 M \mathrm{Na}_{4} \text { EDTA, room temperature, } 3 \text { percent } \\
\text { solids, } 16 \mathrm{hr} \text {. }\end{array}$ & 93 & Seeley, 1976. \\
\hline & $\begin{array}{l}1 M \mathrm{Na}_{2} \mathrm{DTPA} \text {, room temperature, } 3 \text { percent } \\
\text { solids, } 16 \mathrm{hr} \text {. }\end{array}$ & 94 & Seeley, 1976. \\
\hline \multirow{2}{*}{$\begin{array}{l}\text { Alakali-leached } \\
\text { uranium } \\
\text { mill tailings. }\end{array}$} & Distilled water, $25^{\circ} \mathrm{C}, 1$ percent solids, $1 \mathrm{hr}$ & 0.14 & Shearer, 1962 (table 18). \\
\hline & $0.15 M$ EDTA, $60^{\circ} \mathrm{C}, 15$ percent solids, $2 \mathrm{hr}$ & 56 & $\begin{array}{l}\text { Borrowman and Brooks, } \\
1975 .\end{array}$ \\
\hline \multirow{11}{*}{$\begin{array}{l}\text { River bottom }{ }^{1} \\
\text { sediment. }\end{array}$} & Distilled water, $25^{\circ} \mathrm{C}, 1$ percent solids $1 \mathrm{hr}$ & 0.07 & Shearer, 1962 (table 32 ). \\
\hline & $0.01 M \mathrm{HCl}, 25^{\circ} \mathrm{C}, 1$ percent solids, $1 \mathrm{hr}$ & 0.30 & Shearer, 1962 (table 32). \\
\hline & $0.01 M \mathrm{NaCl}, 25^{\circ} \mathrm{C}, 1$ percent solids, $1 \mathrm{hr}$ & 0.07 & Shearer, 1962 (table 32). \\
\hline & $0.01 M \mathrm{KCl}, 25^{\circ} \mathrm{C}, 1$ percent solids, $1 \mathrm{hr}$ & 0.12 & Shearer, 1962 (table 32). \\
\hline & $0.01 M \mathrm{MgCl}_{2}, 25^{\circ} \mathrm{C}, 1$ percent solids, $1 \mathrm{hr}$ & 0.07 & Shearer, 1962 (table 32). \\
\hline & $0.01 M \mathrm{CaCl}_{2} 25^{\circ} \mathrm{C}, 1$ percent solids, $1 \mathrm{hr}$ & 0.40 & Shearer, 1962 (table 32). \\
\hline & $0.01 M \mathrm{SrCl}_{2}, 25^{\circ} \mathrm{C}, 1$ percent solids, $1 \mathrm{hr}$ & 2.12 & Shearer, 1962 (table 32). \\
\hline & $0.015 \mathrm{M} \mathrm{BaCl}, 25^{\circ} \mathrm{C}, 1$ percent solids, $1 \mathrm{hr}$ & 16.5 & Shearer, 1962 (table 33). \\
\hline & $0.01 M \mathrm{BaCl}_{2}, 25^{\circ} \mathrm{C}, 1$ percent solids, $1 \mathrm{hr}$ & $10.1-12.8$ & $\begin{array}{l}\text { Shearer, } 1962 \text { (tables } \\
32,33) \text {. }\end{array}$ \\
\hline & $0.001 M \mathrm{BaCl}_{2}, 25^{\circ} \mathrm{C}, 1$ percent solids, $1 \mathrm{hr}$ & 6.4 & Shearer, 1962 (table 33). \\
\hline & $0.0001 M \mathrm{BaCl}_{2}, 25^{\circ} \mathrm{C}, 1$ percent solids, $1 \mathrm{hr}$ & 0.13 & Shearer, 1962 (table 33). \\
\hline
\end{tabular}

${ }^{1}$ Collected at site 1-2 miles below a uranium mill waste discharge source.

the presence of albite, during the oxidation of ferrous iron in solution by Thiobacillus ferrooxidans, an acidophilic bacterium found frequently in oxidizing pyritic environments. Indeed, the bacterium $T$. ferrooxidans and the mineral jarosite were isolated earlier by Ivarson (1973) from a yellow-brown sediment sampled at the bottom of a pool of highly-acidic water in an underground Elliot Lake mine, yielding pyrite- and pyrrhotite-bearing uranium ore. The possible redistribution and concentration of radium by this or other weathering-associated mechanisms may be of importance in determining the mobility of radium.

- The observation of a sorption-ion exchange type pattern of radium-226 displacement seen with the river sediments is more easily explained as these materials have presumably been chemically contaminated with soluble radium that has sorbed to the clays. and organic matter of the river bottom, as well as physically contaminated by tail- ings discharged by or eroded from the mill area. The replacing power relationship seen here:

$$
\mathrm{Ba}>\mathrm{Sr}>\mathrm{Ca}>\mathrm{Mg}
$$

follows that which might be predicted on the basis of hydrated ionic radii (Grim, 1968).

The geochemical controls on radium mobilization to, and removal from, natural waters has been little studied. Distribution coefficients measured for radium for soil and rock materials at three mill sites in Wyoming, Utah, and Washington range from 8 to $650 \mathrm{~mL} / \mathrm{g}$ (U.S. Nuclear Regulatory Commission, 1978a). Whether these differences reflect technique dependency or actual differences in sorptive capacities is not clear.

Some environmental analyses of subsurface radium migration from uranium mill tailings piles (Sears and others, 1975; U.S. Nuclear Regulatory Commission, 1978a ) have assumed that because of the lack of significant groundwater recharge following the end of mill efflu- 
ent inputs to the tailings pond, and the sorption of radium by earth materials, no significant movement of radium will occur after mill operations cease. The analyses by Sears and others (1975) acknowledges the possible mobilization of radium by ground water as a result of climatic changes that increase leaching by infiltrating precipitation and by inundation by a rising water table. A study of radium and uranium concentrations in ground water samples from the Ogallala formation of the High Plains of Texas and New Mexico showed radium to be present in less than its radioactive equilibrium magnitude (Barker and Scott, 1958); Dyck (1978) indicates that in surficial environments, uranium is more readily leached from soil and rock than thorium-230 and radium-226. The preferential leaching of radium, with respect to uranium, by ground waters (Granger, 1963; Cadigan and Felmlee, 1977 ; Felmlee and Cadigan, 1978b), and in fossil bones (Charalambous and Papastefanou, 1977; Papastefanou and Charalambous, 1978) has been noted in other studies. Differences in the relative mobilities of uranium and radium, as reflected in radioactive disequilibria studies, may be a reflection of local oxidation-reduction conditions affecting the solubility of uranium. However, the fact that high radium ground waters exist around uranium orebodies (Germanov and others, 1958; Cook, 1978; U.S. Nuclear Regulatory Commission, 1978b,c) suggests that natural ground water can mobilize radium from the precursor of the tailings. While it is acknowledged that uranium mill tailings differ physically and chemically from uranium ore, detailed studies of the hydrogeochemical controls on the migration of radium from orebodies may provide valuable information for the assessment of long-term migration of radium from the tailngs deposits, which have histories of only about 30 years or less. This information may also have application to geologic disposal of high-level radioactive waste (spent reactor fuel), as radium-226 is the most hazardous nuclide for exposure by ingestion in such waste aged more than 50,000 years (Gera, 1975).

The character of seepage water draining out of the tailings pile is difficult to predict over the long-term (U.S. Nuclear Regulatory Commission, 1979a). While the waste solutions dis- charged to the tailings pond at a conventional acid-leach mill will be high in sulfates, after the end of milling operations, only natural waters (precipitation and runoff) will be infiltrating the tailings. With time, the sulfate content of the seepage might be expected to decrease, and this may contribute to greater radium mobilization from the tailings.

\section{THORIUM}

In aqueous systems, only the $\mathrm{Th}^{4+}$ oxidation state is known to exist. The tetravalent ion undergoes hydrolysis in aqueous solutions above pH 2 to 3 and is subject to extensive sorption by clay minerals and humic acid at near neutral pH (Bondietti, 1974; Ames and Rai, 1978). In near-neutral $\mathrm{pH}$ and alkaline soils, precipitation of thorium as a highly insoluble hydroxide (Hyde, 1960, indicates $K_{\text {sp }}$ of $\mathrm{Th}(\mathrm{OH})_{4}=$ $10^{-39}$ ) or hydrated oxide phase (Ames and Rai, 1978) and coprecipitation with hydrated ferric oxides (Kluge and others, 1977) may, in addition to adsorption reactions, be important mechanisms for the removal for thorium from solution. Because of sorption and precipitation reactions and the slow solution rate of thoriumbearing resistate minerals thorium levels in natural waters are generally low.

Because of its high charge density, thorium, like uranium, in aqueous solution is susceptible to complex formation. Inorganic and organic, cationic, neutral and anionic, simple and polymeric complexes are known (Cotton and Wilkinson, 1966; Herman and Langmuir, 1978). Studies of soil profiles developed in the glacial moraines of the High Sierra area of California have shown evidence for thorium complexation by, and translocation with, soluble soil organic matter (Hansen and Huntington, 1969). Among the common inorganic anions that form strong complexes with thorium are fluoride, sulfate, phosphate, chloride, and nitrate (Ames and Rai, 1978). Centrifugation, dialysis, and ion exchange studies of thorium in ground waters from granitic terranes (Dement'yev and Syromyatnikov, 1965) suggest its occurrence and transport perodminantly as either a colloidal phase, or as a soluble, anionic complex. The principal chemical characteristics of the ground waters found to contain the most thorium were low $\mathrm{pH}$, low salinity and hardness, and high 
organic content (Dement'yev and Syromyatnikov, 1965). Thus, it would appear that some of the chemical properties of ground water that appear to favor the transport of thorium (high concentration of sulfate, low concentration of calcium, and low ionic strength) may inhibit the ground water transport of radium.

The liquid effluents discharged to the tailings pond may contain a variety of organic compounds from the solvent extraction circuit or other stages in the milling process. Also, carbonaceous materials in uranium ores, which may be dissolved in the milling process (Dreesen and others, 1978), are discharged with the tailings. As organic complexes of thorium have been shown to be of importance in natural water systems, the influence of both natural and process-reagent organic species on the environmental mobility of thorium-230 should be evaluated. The presence of complexing agents in these effluents has been offered as a partial explanation for the low distribution coefficients observed for thorium-230 on subsoil materials equilibrated with tailings pond water from a Wyoming millsite (D'Appolonia Consulting Engineers, Inc., 1977).

The waste stream $(\mathrm{pH} \mathrm{10)}$ at the Humeca uranium mill contains about $110 \mathrm{pCi} / \mathrm{L}$ of thorium-230 (U.S. Environmental Protection Agency, 1976b). At lower pH's, thorium becomes more soluble. Acid-leach milling may dissolve from 30 to 90 percent of the thorium in the ore (Robertson, 1962; Moffet, 1976; Ryon and others, 1977; Levins and others, 1978). Acidic effluents ( $\mathrm{pH}$ 2.5) from uranium mills in the Grants Mineral Belt of New Mexico contain from 150,000 to $170,000 \mathrm{pCi} / \mathrm{L}$ of thorium-230 (Kaufmann and others, 1976). The solubilized thorium can be subsequently precipitated if the acidic effluent is neutralized, either by contact with natural media or by process additions of lime and (or) limestone to the waste solutions. At Elliot Lake, Ontario, current practice involves raising the $\mathrm{pH}$ of the tailings slurry to about $\mathrm{pH} \mathbf{1 0 . 5}$ with lime upon impoundment (Raicevic, 1978). At the Sherwood uranium mill (acid-leach) in eastern Washington, the tailings slurry is neutralized (from an initial $\mathrm{pH}$ of about 1 to a final $\mathrm{pH}$ of about 7) by the addition of lime prior to discharge to the tailings pond (U.S. Depart- ment of the Interior, 1976); however, at most active mills in the United States, the waste stream is not neutralized. Neutralization of the waste solutions by contact with the alkaline subsoils which underlie the tailings ponds at most western sites will likely result in the precipitation or coprecipitation of thorium as noted above.

\section{URANIUM}

The dominant uranium valence states, which are stable in geologic environments, are the uranous $\left(\mathrm{U}^{4+}\right)$ and uranyl $\left(\mathrm{U}^{6+}\right)$ states, the former being far less soluble. The $\mathrm{U}^{4+}=\mathrm{U}^{6+}$ transition has a redox potential within the normal range for geologic environments (Langmuir, 1978),

$$
\mathrm{U}^{4+}+2 \mathrm{H}_{2} \mathrm{O}=\mathrm{UO}_{2}{ }^{2+}+4 \mathrm{H}^{+}+2 \mathrm{e}^{-} .
$$

The standard oxidation potential $\left(25^{\circ} \mathrm{C}\right)$ is $\mathrm{E}^{\circ}=+0.27$ volts. Uranium transport generally occurs in oxidizing surface and ground waters as the uranyl ion, $\mathrm{UO}_{2}{ }^{2+}$, or as uranyl floride-, phosphate-, or carbonate-complexes. These complex ions include neutral, cationic-, and anionicspecies. The uranyl ion and uranyl fluoride complexes dominate in oxidizing, acidic waters, while the phosphate- and carbonate- complexes dominate in near-neutral and alkaline oxidizing waters, respectively. Hydroxyl-, silicate-, organic-, and sulfate-complexes may also be of importance, the latter especially in mining and milling operations using sulfuric acid as a leaching agent (Langmuir, 1978). In weakly acid waters high in dissolved organic matter, uranium may be transported as a pseudocolloidal phase (Kochenov and others, 1965).

Soils and related materials have been shown to sorb significant quantities of uranium. Masuda and Yamamoto (1971) showed that 10-g soil samples (pH 5.4-5.8) were able to sorb all of the uranium (supplied as uranyl nitrate) from $100 \mathrm{~mL}$ of aqueous solutions containing 1 to $100 \mu \mathrm{g} / \mathrm{mL}$ of uranium. The quantity of uranium adsorbed was not related to the soils' cation exchange capacities. Szalay (1964) showed peats to sorb up to $2-3$ meq $\mathrm{UO}_{2}{ }^{2+} / \mathrm{g}$ and suggests the sorption is a cation exchange process. Dement'yev and Syromyatnikov (1968) showed maximal sorption of hexavalent uranium by colloidal humic acid, fulvic acid, 
coal, and iron oxides to occur at $\mathrm{pH} 5$ to 6 . Langmuir (1978) reports maximal sorption of uranyl ions on natural materials (organic matter, iron-, manganese-, and titanium-oxyhydroxides, zeolites, and clays) to occur at $\mathrm{pH} 5.0$ to 8.5. The sorption of uranyl ions by such natural media appears to be reversible, and for uranium to be "fixed" and thereby accumulate, it requires reduction to $\mathrm{U}^{4}+$ by the substrate or by a mobile phase such as $\mathrm{H}_{2} \mathrm{~S}$ (Kochenov and others, 1965; Langmuir, 1978).

\section{WATER QUALITY STUDIES}

GRANTS MINERAL BELT IN NEW MEXICO

The most extensive study to date on the effects of uranium mining and milling operations on ground water quality was done by the U.S. Environmental Protection Agency (EPA) in the Grants Mineral Belt area of northwestern New Mexico in 1975 (U.S. Environmental Protection Agency, 1975; Kaufmann and others, 1976; Eadie and Kaufmann, 1977). This area contains about 40 percent of the Nation's uranium reserves and presently has five inactive tailings piles, five active mills and seven mills in the proposal, design, or construction phase. Ground-water contamination in these milling areas can occur as a result of seepage from active tailings ponds, or inactive tailings piles, or from leakage out of the zone of injection from disposal well operations. Seepage from the tailings ponds in the Bluewater Valley and the Ambrosia Lake areas amounted to about 180,000 and $491,000 \mathrm{~m}^{3} / \mathrm{yr}$, respectively, for the period 1973-1974. These quantities represent about 8 and 29 percent, respectively, of the inflow to the ponds.

While mill effluents (sampled at the Bluewater mill over the period 1960-1975) contained from 40 to $292 \mathrm{pCi} / \mathrm{L}$ of radium-226, only one of the 71 existing wells sampled in the region (well depths ranging from 8.2 to $299 \mathrm{~m}$ ) showed radium-226 concentrations in excess of $5 \mathrm{pCi} / \mathrm{L}$. This sample contained 6.6 $\mathrm{pCi} / \mathrm{L}$ of radium-226 and was obtained from a shallow $(8.2 \mathrm{~m})$ well adjacent to an active tailings pond in the Ambrosia Lake area.

While the active mills discharge no waste solutions to the surface waters, mine drainage waters do enter surface water courses, and as shallow ground waters in these areas most commonly occur in valley fills, which may be recharged by surface water, the potential for ground-water contamination from this source exists. The radium content of mine drainage waters varies greatly with the stage of development of the mine, that is, the degree of exposure of the orebody. Mine drainage waters samples during the period 1970-1975 in the Churchrock and Jackpile-Paguate areas had radium-226 contents ranging from 8 to 190 $\mathrm{pCi} / \mathrm{L}$. However, the EPA study failed to reveal ground-water contamination as a result of mining operations.

Non-radioactive constituents in the mine and mill effluents can lead to elevated levels of total dissolved solids, ammonia, nitrate, selenium, and vanadium in surface and ground waters. Selenium probably occurs as the selenite anion in oxidizing, alkaline waters (Hem, 1970), and is an element of concern in the vicinity of an alkaline-leach mill in the region. Shallow, downgradient, off-site, domestic wells containing up to $3.9 \mathrm{mg} /$ of selenium (EPA Interim Primary Drinking Water Standard is $0.01 \mathrm{mg} \mathrm{Se} / \mathrm{L}$ ) have been observed here, the contaimination of the shallow aquifer presumably caused by seepage through the sandy soil from the adjacent tailings pond. Periodic resampling of selected wells in the EPA study is advisable to provide a data base for future evaluation of the environmental effects of mining and milling in the Grants area.

\section{ELLIOT LAKE, ONTARIO}

Important uranium deposits exist in the Elliot Lake area of southeastern Ontario, Canada. In contrast to the Grant Mineral Belt's mean annual precipitation of $25 \mathrm{~cm}$ and evaporation potential of $180 \mathrm{~cm}$ (Ford, Bacon, and Davis Utah, Inc., 1977, GJT-13), the wettemperate Elliot Lake area is characterized by a mean annual precipitation of $80 \mathrm{~cm}$ and evaporation of about $60 \mathrm{~cm}$ (Hare and Thomas, 1974). The uranium ore contains about 3-8 percent pyrite, and hence upon oxidation, there exists the opportunity for extensive sulfuric acid leaching of the tailings.

Moffett and Tellier (1978) have examined the tailings solids and ground water contained within the pile at a 17-year old abandoned uranium mill tailings area at Elliot Lake. 
Thorium, originally present in the ore at 170 $\mu \mathrm{g} / \mathrm{g}$, was reduced to $4-6 \mu \mathrm{g} / \mathrm{g}$ in the upper 15 $20 \mathrm{~cm}$ of the weathering tailings. It should be recognized that the concentration of thorium in the ore-feed may have varied during the life of the tailings pond. Also, some of the thorium solubilized during the acid milling of the ore may not, due to incomplete neutralization of the mill effluent, have been precipitated and deposited with the tailings solids sampled. Nevertheless, it would appear that much of the thorium present in the tailings solids at the time of deposition has since been lost to surface and ground waters. These tailings also show evidence of the leaching loss of uranium and radium-226, although again, the apparently diminished levels may reflect changes in the ore grade having gone through the mill, and sampling variations associated with the heterogeneity of the tailings pile.

The ground waters sampled within the tailings pile are grouped into two acidity classes. The low acidity group samples (acidity $<1000$ $\mathrm{mg} / \mathrm{L}$ as $\mathrm{CaCO}_{3}$ ) were all obtained from the slime-rich zones of the pile (where pyrite oxidation is restricted owing to a lack of dewatering) and were generally lower in total dissolved solids, iron, zinc, uranium, lead-210, and gross $a$ and $\beta$ activity than those samples in the high acidity group. While the low acidity waters showed no detectable thorium, the high acidity waters showed up to $2,100 \mathrm{pCi} / \mathrm{L}$ of thorium-228, 4,200 $\mathrm{pCi} / \mathrm{L}$ of thorium-232, and $52,000 \mathrm{pCi} / \mathrm{L}$ of thorium-230. In contrast to the trend observed for the other radioisotopes, radium-226 levels were generally higher in the low acidity $($ mean $=113 \mathrm{pCi} / \mathrm{L})$ as compared to the high acidity $($ mean $=59 \mathrm{pCi} / \mathrm{L})$ waters (Moffett and Tellier, 1978). This may be due to the suppression of $\mathrm{RaSO}_{4}$ dissolution in the zones of active pyrite oxidation caused by the high sulfate concentrations in the interstitial waters.

The leaching of radionuclides from abandoned Elliot Lake tailings has been studied in laboratory columns by Schmidtke and others (1978). These tailings initially contained 122 $\mathrm{pCi} / \mathrm{g}$ of radium-226 and $3.2 \mathrm{pCi} / \mathrm{g}$ of thorium-230. Using water application rates of 49 $\mathrm{mm} / \mathrm{yr}$, the leachate contained $81 \mathrm{pCi}$ radium$226 / \mathrm{L}$ initially, decreasing in 2.3 years to 5
$\mathrm{pCi} / \mathrm{L}$, and $1565 \mathrm{pCi} / \mathrm{L}$ of thorium-230, initially, decreasing in 2.3 years to $693 \mathrm{pCi} / \mathrm{L}$.

\section{OTHER AREAS}

The U.S. Department of Energy has recently issued a series of 20 reports prepared by Ford, Bacon, and Davis Utah, Inc., dealing with inactive uranium mill tailings piles in eight Western States (Ford, Bacon, and Davis Utah, Inc., 1976, 1977). These reports are engineering assessments of possible methods and costs of cleanup of these sites, and include sitespecific information on tailings characteristics and ground water and soil contamination.

The tailings sampled at the various piles were found to have a maximum radium-226 concentration ranging from about 100 to 5,000 $\mathrm{pCi} / \mathrm{g}$.The depth of leaching of radium into the soil beneath most of the tailings (generally defined in these reports as the depth at which the soil radium-226 levels fall to twice background levels) ranged up to about 8 feet. At several of the sites (Monument Valley and Tuba City in Arizona, Durango, Naturita, and Rifle in Colorado, Ambrosia Lake in New Mexico, and Falls City in Texas) there were indications of local ground and surface water contamination with respect to $\mathrm{Ra}-226$, presumably caused by seepage and runoff from the tailings piles, although with the exception of the Ambrosia Lake and Falls City sites, EPA drinking water standards were generally not exceeded at the time of sampling (Ford, Bacon, and Davis Utah, Inc., 1977, GJT $-4,6,8,10,13$, 16). At the Naturita, Grand Junction, Old Rifle, and Gunnison sites, the water table within the alluvium on which the tailings piles rest is very shalow, and at times may rise within the tailings, thereby creating the potential for unconfined ground water to leach the tailings (Ford, Bacon, and Davis Utah, Inc., 1977, GJT-8,9,10,12).

\section{URANIUM MILL TAILINGS TREATMENT AND DISPOSAL OPTIONS}

\section{SURFACE STABILIZATION OF TAILINGS AND NEAR SURFACE BURIAL}

The tailings are non-cohesive, small rock fragments, and thus highly susceptible to erosive forces. They generally do not have the physical and chemical properties required to 
sustain plant growth, and therefore will not be amenable to direct stabilization by vegetation. To date, many inactive tailings piles remain uncovered and unvegetated, and thereby subject to severe wind and water erosion. Stabilization efforts to date have generally involved contouring of the pile, application of a thin earth cover (topsoil, gravel, riprap on steep slopes), vegetation, and construction of drainage ditches to divert surface runoff water from neighboring land from reaching and eroding the piles.

Climatic considerations, such as lack of adequate rainfall for plant growth, and the low fertility of cover materials often require the use of mulches, fertilizer, and irrigation water in order to establish a vegetation stand. While it is certainly possible, with human intervention and application of soil amendments, to establish vegetation on these tailings and cover materials, at present there has been insufficient research and time to evaluate whether or not permanent, maintenance-free vegetative stabilization can be successfully achieved. The record to date is spotty. While at some locations thick vegetation stands have been achieved, these have often required repeated irrigation. Visible erosion following stabilization attempts have been reported (Ford, Bacon, and Davis Utah, Inc., 1977, GJT-18).

In areas where stabilization with vegetation is not feasible because of lack of sufficient rainfall, chemical stabilization methods have been proposed and (or) tried. The use of a water-soluble, elastomeric polymer tailingsbinding agents was tested on the Tuba City, Ariz., uranium mill tailings in September 1968 (Havens and Dean, 1968). A May 1974 inspection of the site showed extensive disintegration of the initially indurated crust (Ford, Bacon, and Davis Utah, Inc., 1977, GJT-5). Decomposition of the stabilization crust within 2 to 3 years was observed following the test application of a tar-like agent to the surface of a portion of the tailings at the inactive mill site in Salt Lake City, Utah (Ford, Bacon, and Davis Utah, Inc., 1976). A major loss of the radon-flux attenuating abilities of a plasticized sulfur compound was observed in 2 years at uranium mill tailings test plots near Las Vegas, Nev. (Bernhardt and others, 1975; Macbeth and others, 1978) .The placement of a coarse rock cover over the soil cap in order to approximate a natural "desert pavement," and thereby armor the soil cap has been suggested as a means of prolonging the period of tailings burial (Nelson and Shepard, 1978). A coarse rock cover has been used with some success in minimizing wind and water erosion of tailings at the inactive mill site near Shiprock, N. Mex. (Nelson and Shepard, 1978). A gravel cover will apparently be used in the final stabilization of the tailings derived from a mill in southeastern Utah, which was recently considered for relicensing (U.S. Nuclear Regulatory Commission, 1979b).

The use of "below-grade" burial of tailings in pits, and the use of $3 \mathrm{~m}$ or more of cover earth, as advocated by the NRC (U.S. Nuclear Regulatory Commission, 1979a), will provide for a longer period of erosional stability than that associated with "above-grade" impoundment of tailings, the common disposal method at the inactive sites and older active sites. "Below-grade" disposal will not result in remnant tailings piles above the land surface, and thus the component cover materials and tailings will be less susceptible to wind and water erosion than those in "above-grade" structures. However, cover materials and tailings in "below-grade" disposal systems, as well as the surrounding land surface, are, nevertheless, subject to erosion.

"Stability" is a time-dependent concept. A concept whose time-focus is that of human life spans and the life spans of man-made structures is inadequate in assessing the fate of materials whose radioactive character persists over hundreds of thousands of years. Schumm (1963) reports average denudation rates of 9 to $20 \mathrm{~cm} / 1,000 \mathrm{yr}$ for arid/semi-arid terranes [average annual precipitation of 25 to $38 \mathrm{~cm}$ (10-15 inches)]. Using the lower end of this

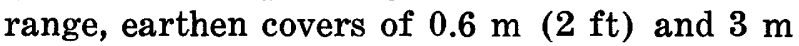
(10 ft) in thickness would be removed in about 6,700 and 33,000 years, respectively. During these time periods about 6 and 26 percent, respectively, of the thorium-230 will have decayed, and without subsequent reburial, the tailings, with the bulk of their radioactive complement, thus may be exposed to wind and water erosion. 
The rates of disinterment presented require qualification. The regional denudation rates used do not consider local conditions such as position in drainage basin and topographic features providing wind breaks (U.S. Nuclear Regulatory Commission, 1979a), which may cause local erosion rates to deviate considerably in either direction from the regional mean. Neither do the disinterment rates consider climatic changes in the future that can alter erosion rates. Manipulated soil covers are likely to be more susceptible to erosion than natural soils or bedrock. Grazing and burrowing activities of animals may increase the erosion rates (Whicker, 1978). On the other hand, newlydesigned tailings disposal areas (U.S. Nuclear Regulatory Commission, 1978d) will probably be covered and contoured to yield a low relieflength ratio; hence the regional denudation rates presented above may overestimate the rate of disinterment. Also, the consideration of regional denudation rates emphasizes erosional processes to the exclusion of depositional processes that may be of local importance in a given area. Indeed, siting of tailings disposal areas in aggrading portions of landscape may be beneficial as depositional processes would tend to maintain a cover above the tailings, and thus attenuate dispersal as well as radon exhalation and gamma radiation exposure (U.S. Nuclear Regulatory Commission, 1979a). These potential benefits associated with an aggrading geomorphic surface may, however, be offset if the area is also a ground-water recharge zone.

Radon emanation can be controlled by covering the tailings with either liquids or solids, thereby decreasing the diffusion rate of the radon and allowing for its decay (half-life of radon-222 is 3.8 days) prior to atmospheric emergence. A water cover of $60 \mathrm{~cm}(2 \mathrm{ft})$ can reduce radon emanation by about 96 percent (U.S. Environmental Protection Agency, 1973). However, long-term maintenance of a ponded situation may not be possible after mill operation ceases, nor is it a desirable situation from the standpoint of seepage of radium and other contaminants into the subsurface.

Two feet of earth will theoretically reduce radon emanation, with respect to the bare tailings, by about 25-60 percent (U.S. Environmental Protection Agency, 1973; Sears and others, 1975). ${ }^{6}$ A recent NRC position paper (U.S. Nuclear Regulatory Commission, 1977a) indicates that a major goal of uranium mill tailings management programs should be the reduction of radon emanation rates from inactive tailings impoundment areas to about twice that of the emanation rate in the surrounding environs. ${ }^{7}$ Assuming an average background radon emanation rate of about $1 \mathrm{pCi}$ $\mathrm{m}^{-2} \mathrm{~s}^{-1}$ (Wilkening, 1974; Martin and Miller, 1978) and a radon flux from a typical exposed tailings pile of about $500 \mathrm{pCi} \mathrm{m}{ }^{-2} \mathrm{~s}^{-1}$ (Clements and others, 1978), the NRC goals require about a 99.6 percent reduction in radon emanation. Depending upon the cover materials particle size distribution, bulk density, moisture content, and other properties affecting the permeability to radon migration, a thickness of about 3 to $12 \mathrm{~m}$ (10-40 ft) or more of earth will be required for a 99 percent reduction in radon emanation from the underlying tailings (U.S. Environmental Protection Agency, 1973; Sears and others, 1975; Macbeth and others, 1978; Nelson and Shepard, 1978). Thus to reduce radon emanation to a maximum extent, particularly in view of the erosion rates previously cited, burial of the tailings in a deep excavation or cavity would be most effective. While concrete, asphalt, and organic binding agents may provide marked reductions in radon

\footnotetext{
${ }^{6}$ Radon measurements were made in the atmosphere above the uranium mill tailings pile at Grand Junction, Colo., in 1967-68, during the active life of the mill, and again in 1974-75, following the stabilization of the inactive tailings pile with a 6 -inch soil cover in 1970 (Duncan and others, 1977). Although the comparative data is limited to only two stations, it suggests that the mean annual radon concentration measured above the tailings pile after stabilization was about three times that measured before stabilization. This result is probably associated with the differing moisture contents of the pile at the different sampling times. In $1967-68$ portions of the pile were ponded as a result of the input of mill effluents, while in 1974-75 the tailings were much drier, the only moisture inputs to the pile being the natural precipitation and occasional irrigation waters. This decreased moisture content would allow radon to diffuse more rapidly within the tailings pile and thus more radon would reach the atmospheric interface before its radioactive decay. Other possibly contributing factors in the poststabilization increase in atmospherc radon concentratons include: (1) The redistribution of tailings during contouring operations performed as part of the stabilization program and the resultant changes in pile depth, surface area and relative position, with respect to the surface, of high-radium slime zones and (2) The action of plant roots, burrowing animals, and dessication and settling cracks in penetrating the soil cap and tailings, and thereby creating channels for radon movement.

7 The proposed radon flux limit in the draft generic environmental impact statement on uranium milling prepared by the U.S. Nuclear Regulatory Commission (1979a) is given as $2 \mathrm{pCi} \mathrm{m}^{-2} \mathrm{~s}^{-1}$ rather than as an increment of background.
} 
flux in laboratory and short-term field trials, their long-term physical and chemical stability in the weathering environment should be considered.

Cover materials will also affect levels of gamma radiation exposure from the pile. The cover, by virtue of its shielding character, will produce a net attenuation of the exposure rate. Each $30 \mathrm{~cm}$ (1 ft) of packed earth will theoretically reduce the exposure rate by a factor of about ten (Swift and others, 1976). Thus, for a typical pile (see pg. 8), a $120 \mathrm{~cm}$ (4-ft) earthen cover should reduce the surface exposure rate on the pile to about $1 \mathrm{mR} /$ year. Current NRC licensing guidelines (U.S. Nuclear Regulatory Commission, 1977a) call for the reduction of direct gamma radiation from reclaimed tailings impoundment areas to essentially background levels ( about $150 \mathrm{mR} / \mathrm{yr}$ in Western States where most uranium is mined). While the relatively thick covers, 3-5 m (10-15 feet), proposed for new mill tailings reclamation projects will certainly achieve such control levels, their removal by erosion over geologic time will progressively restore both the radon flux and gamma exposure rate to their uncovered values.

\section{RADIUM REMOVAL FROM TAILINGS}

An alternative to the controlled storage of radioactive mill tailings would be the removal of the uranium daughter products, either initially from the ore at the time of milling, or from the tailings subsequently, to produce a radiologically-innocuous crushed-rock material, and a radioactive concentrate. Borrowman and Brooks (1975) showed that from 92 to 96 percent of the radium in uranium ores was leached (25 percent solids slurry) by two, 30-minute, $60^{\circ} \mathrm{C}$ treatments with $1.5 \mathrm{M} \mathrm{HCl}$. More than 99 percent of the uranium present in the ore was leached by this treatment. Following uranium removal, the leach liquor was lime-neutralized and dosed with barium chloride and sodium sulfate to coprecipitate the leached radium with barium sulfate. Greater than 99 percent radium removal was achieved thereby in a $\mathrm{BaSO}_{4}$ precipitate having 4 percent of the weight of the ore treated .As thorium-230 is the long-lived parent isotope of radium-226, thorium removal would be an essential compo- nent of any adopted milling process aimed at radium removal from the tailings. Thorium, like radium, forms acid-soluble chloride salts (Rogers and Adams, 1969), and hence its removal from the tailings by an $\mathrm{HCl}$ leaching process would also appear possible. Concentration of thorium in solution by coprecipitation with barium sulfate may be possible (Ambe and Lieser, 1978). For this reason, the radium concentrate proposed above may also contain much of the thorium. Alternate procedures for the concentration of the thorium-230 from uranium mill effluents by a combination of ion exchange, coprecipitation, and solvent extraction procedures, followed by precipitation of thorium hydroxide have been proposed by Kluge and others (1977).

Borrowman and Brooks (1975) also found 92-95 percent radium removal by $1.5-3.0 M$ $\mathrm{HCl}$ from acid-processed uranium mill tailings. Thus "detoxification" of existing tailings would appear possible. The remilling of tailings for recovery of residual uranium offers an opportunity for such a radium removal. The inactive uranium mill tailings examined by Ford, Bacon, and Davis Utah, Inc. $(1976,1977)$ had residual uranium contents of from 0.005 to 0.049 percent (by weight) $\mathrm{U}_{3} \mathrm{O}_{8}$, and with present-day technology it appears economically feasible to reprocess tailings with greater than about 0.02 to 0.03 percent $\mathrm{U}_{3} \mathrm{O}_{8}$.

Work at Oak Ridge National Laboratory focusing on nitric acid leaching of uranium ores and tailings has shown removals of 85-98 percent of the radium-226 by a two-stage leach with $3 \mathrm{M} \mathrm{HNO}_{3}$ at 33 percent solids for 5 hours at $70^{\circ} \mathrm{C}$ (Ryon and others, 1977). Thorium-230 removals from these ores and tailings under identical leaching conditions were 92-99 percent, and uranium removals from the ores were greater than 99.5 percent. Conversion of the extracted radium- and thorium-nitrates to an oxide form by heating and fixation of this oxide concentrate, in asphalt for example, prior to burial may be a possible disposal technique (U.S. Nuclear Regulatory Commission, 1979a). Thus, nitric acid leaching offers another possible method for producing a radium- and thorium-depleted tailings material, although problems related to ground-water contamination by nitrates from waste solutions would 
probably exist with such a system. Neither the $\mathrm{HCl}$ nor $\mathrm{HNO}_{3}$ milling of ores or tailings has yet been commercially-adopted, probably because of a combination of concerns, including those regarding the field-scale feasibility and the higher projected capital and operating costs of such processes as compared to conventional sulfuric acid milling and the disposal of radioactive concentrates and residual materials. Levins and others (1978) have studied the use of low-cost sodium chloride for the leaching of radium from uranium mill tailings. While over 90 percent removal is achieved by four-stage leaching of acid-milled tailings in $5 M \mathrm{NaCl}$ solutions at $25^{\circ} \mathrm{C}$, the process does not remove thorium-230, hence, the long-term source for radium-226 remains in the tailings.

Raicevic (1978) has developed a flotation procedure which removes about 60-75 percent of the uranium, thorium and radium-226, as well as about 95 percent of the pyrite in samples of Elliot Lake tailings, and concentrates them in a fraction of about 25 percent the weight of the original tailings. Flotation tests by the U.S. Bureau of Mines on acid-leached tailings from the inactive, Salt Lake City site, like thuse of Raicevic (1978), yielded a radiumrich gypsum concentrate (Borrowman and Brooks, 1975). However, the flotation techniques tried were less effective than sand-slime separation by simple sedimentation, the latter process achieving a concentration of 94 percent of the radium-226 into a slime fraction representing 25 weight-percent of the original tailings.

Because of their higher radionuclide levels, the concentrates derived from the physical or chemical separation of the radium-226 and other radionuclides from the tailings will probably require a higher level of control than the original tailings. Recent work sponsored by the Canada Centre for Mineral and Energy Technology focused on the chemical and biological stability of the $\mathrm{Ba} / \mathrm{RaSO}_{4}$ sludges. While radon emanation from such precipitates is reported to be low (Hahn, 1936), radium may be released from them as a result of chemical leaching by natural water and (or) as a result of the microbial metabolism of the precipitate by anaerobic, sulfate-reducing bacteria present in soils and waters (pers. commun., R. G. L.
McCready. As radium in sulfuric acid-leached mill tailings may also exist as a mixed alkaline earth-sulfate precipitate (Seeley, 1976), these same microbial and chemical processes may also be operative in conventional tailings disposal systems.

The level of control required for the residual material will depend upon the degree of decontamination achieved. Neither research nor regulatory efforts to date have clearly established a "safe" level of radium-226 in earth materials destined for unrestricted environmental disposal. A radium-226 concentration of about $20 \mathrm{pCi} / \mathrm{g}$ has been suggested as a goal for the unrestricted storage of tailings by Borrowman and Brooks (1975) and Schiager (1977). The U.S. Environmental Protection Agency $(1978 \mathrm{a}, \mathrm{b})$ has proposed a radium concentration of $5 \mathrm{pCi}$ of radium-226/g as the lower limit for designation of uranium and phosphate milling and processing solid wastes as "hazardous," and thereby requiring regulated disposal and ground-water monitoring. In contrast, the State of Louisiana has adopted a regulation establishing $0.1 \mathrm{pCi} / \mathrm{g}$ as the maximum allowable concentration of radioactive material (nuclides not specified) in mineral tailings not subject to radiation safety disposal requirements (Conference of Radiation Control Program Directors, 1978). Such a standard would appear to be untenable with respect to radium-226 as its average crustal abundance is about $1 \mathrm{pCi} / \mathrm{g}$ (Rankama and Sahama, 1950; Borrowman and Brooks, 1975). However, work at Elliot Lake, Ontario (Mooney and Scott, 1978; Dilworth, Secord, Meagher and Associates Ltd., 1979) suggests that glacial sands with a total radium concentration of only $1 \mathrm{pCi} / \mathrm{g}$ and an emanation coefficient of 20 percent may produce unacceptable radon daughter concentrations in overlying dwellings.

\section{PRECONCENTRATION OF URANIUM ORE}

The pre-milling sorting or beneficiation of the uranium ore into a high- and a low-activity fraction has been suggested by Canadian workers (Lush and others, 1978) as a means of reducing the quantity of radioactive tailings generated. The high activity fraction containing most of the uranium and uranium-daughter products would be milled, and yield a tailings 
having an estimated mass of about 20-50 percent that of conventional milling, while containing two to five times more radium and other uranium daughter products per unit mass. This smaller quantity of more concentrated tailings would presumably be more amenable to waste management. The fate of the non-milled, low activity fraction is not discussed.

Preconcentration of certain types of uranium ores by high speed lump sorting machines equipped with radiometric detectors would appear to be technically attainable and economically desirable (Smith and White, 1969). A gravity-flotation technique tested on a quartzpebble conglomerate, Elliot Lake ore achieved a bulk reduction of 2 or $3: 1$ with a 90 percent recovery of uranium (Honeywell and Kaiman, 1966).

The bulk of the uranium ores presently milled in the United States are low grade (about 0.1-0.2 percent $\mathrm{U}_{3} \mathrm{O}_{8}$ ) sandstone deposits in which the uranium coats the sand grains and fills the interstices (Harshman, 1970), and thus would not appear to be amenable to upgrading by lump sorting. The physical upgrading of these ores by other mineral beneficiation methods may be possible, although no such research- or commercial-scale operations are known to the author. Preconcentration by sizing had been used at several, now-inactive upgrading plants and mills in the United States with such sandstone ores. This process yielded a slime concentrate high in uranium and its daughter products, and a sandy fraction which was discharged to a tailings pond (Merritt, 1971). Such efforts were aimed at producing an acceptable mill feed from low-grade ores and (or) at reducing the cost of shipping ore to the mill. They did not influence the overall waste management problem, as the tailings from such upgrader operations, and similarly the segregated sand fractions of tailings at conventional mills, contain too much radium and other potentially detrimental elements for unrestricted disposal. Preconcentration of ore and the segregation for disposal of the lowactivity fraction may be of value in the waste management area, but only if that reject fraction is sufficiently low in radioactive and toxic elements as to justify a lesser degree of envi- ronmental control than the tailings from the processing of the high-activity fraction.

\section{DEEP BURIAL IN UNDERGROUND CAVITIES}

Deep burial provides for longer periods of isolation prior to disinterment by erosive forces, as well as greater long-term attenuation of radon exhalation and gamma radiation exposure, than shallow burial. Underground excavation is expensive and with the large volume of tailings to be buried, the construction of cavities solely for such disposal is highly unlikely. For this reason, emplacement in abandoned mine shafts and drifts is the most likely option for deep disposal of tailings. While cavities from various mining operations may potentially be available, proximity to mill sites makes those associated with underground uranium mining the most likely candidates. At present, about 50 percent of the uranium (based on quantity of $\mathrm{U}_{3} \mathrm{O}_{8}$ ) produced in the United States is associated with underground mining. About 56-70 percent of the presentlyestimated $\$ 30$-uranium ore reserves ${ }^{8}$ lie at depths greater than 90-150 m (300-500 ft), allowing for recovery largely by underground, and perhaps solution mining, as opposed to open pit mining (U.S. Department of Energy, 1978). Because of the large volume of tailings generated by the milling of open pit-mined ores, as well as the bulking (the increase in volume of material owing to manipulation of the tailings as compared to the in-place ore) and the collapse of cavities at depth owing to the mining of pillars, the volume of underground space associated with uranium mining available for the potential disposal of tailings is obviously inadequate to handle all of the tailings that will be produed.

Deep burial may put tailings in contact with aquifers and thereby introduce radioactive and non-radioactive contaminants into the ground water. Whether such disposal is environmentally-acceptable will be dependent upon many factors including the chemical form and quantity of the elements of concern in the tailings, the ability of the ground water to leach these constituents from the tailings, the chemical

\footnotetext{
${ }^{8}$ Ore that is estimated to be recoverable by mining at costs equal to or less than $\$ 30$ per pound of $\mathrm{U}_{3} \mathrm{O}_{\text {s. }}$.
} 
form of the leached constituents (anions, cations, uncharged species, or colloids), the sorptive capacity of the aquifer for the species of concern, the rate of ground-water flow, the distance from the disposal zone to discharge areas, the initial water quality in the aquifer, and the present and projected usage of the ground water.

\section{THICK-UNSATURATED ZONE STORAGE}

Unsaturated zones of $100 \mathrm{~m}$ thickness are common in Southwestern United States beneath the upper reaches of piedmont alluvial fans, and zones 100-600 $\mathrm{m}$ thick may occur beneath selected mesas, plateaus, and sometimes even beneath valley floors. Even if the climate of a future pluvial time should approach subhumid conditions, a major rise in the water table would appear to be unlikely at such sites provided there is moderate to high relief, relatively permeable rocks occur within the unsaturated zone, and regional aquifers with topographically low outlets underlie the sites (Winograd, 1974). It has been suggested that burial of high level radioactive wastes in such thick unsaturated zones be evaluated (Winograd, 1974). Such a proposal may also have merit for the storage of uranium mill tailings or tailings concentrates. Buriai of tailings in an excavation at a depth of about $30-40 \mathrm{~m}$ in a thick unsaturated zone should reduce radon emanation to near background levels, limit the potential for inundation of the tailings by a rising ground-water table, and provide for radioactive decay over the course of at least two to three half-lives of thorium-230 prior to disinterment by erosion.

The excavation of such burial pits, unaccompanied by ore recovery, will undoubtedly be quite expensive. The transport of tailings to such burial sites from distant mills would have to involve pipeline or rail transfer, and thus would be both costly and introduce new potential avenues for environmental contamination.

\section{FIXATION AND AGGLOMERATION OF BURIED TAILINGS}

Incorporation of tailings into an asphaltic or concrete matrix has been considered in several conceptual evaluations of uranium mill tailings storage options (Sears and others, 1975; Martin and Miller, 1978), although apparently there have been no published reports on the experimental evaluation of such procedures. The costs for such a venture would appear to be high, and the long-term stability of the binding between tailings and cement or asphalt is not known (Martin and Miller, 1978). The decomposition of a tar-like, surface-stabilizing agent within 2 to 3 years after application was observed in a 1969 field test at the inactive uranium mill tailings site in Salt Lake City, Utah (Ford, Bacon, and Davis Utah, Inc., 1976). Koehmstedt and others (1977) have studied the use of 3 to $6 \mathrm{~mm}(0.12-0.24 \mathrm{in})$ thickness of asphalt emulsion applied to uranium mill tailings as a means of limiting radon emanation. While quite effective in short-term laboratory studies, such sealants are acknowledged to be susceptible to degradation by physical (freeze and thaw, ultra-violet radiation), chemical (by action of oxygen, ozone, salts, acids and alkalies), and microbiological reactions, and thus their application would not appear to provide a long-term solution to the tailings problem.

Wiles (1978) has found that the pelletizing, firing and glazing (by incorporation of 5-10 percent powdered glass, $\mathrm{CaF}_{2}$ or $\mathrm{Fe}_{2} \mathrm{O}_{3}$ ) can reduce the leaching of radium from uranium mill tailings in tests of up to 20 days by up to three orders of magnitude. Again, long-term mechanical and chemical stability of these pelletized materials in the natural environment is not known.

\section{IN-SITU LEACH MINING}

In-situ leach mining refers to a selective extraction technique whereby ore minerals in their natural geologic setting are preferentially dissolved from the surrounding host rock by specific leach solutions and the mineral value recovered. In-situ operations for uranium recovery presently exist at about 20 sites; most are in Wyoming and Texas. The general procedure consists of injecting a leach solution ("lixiviant"-generally ammonium carbonate, sodium carbonate or sulfuric acid) into the ore zone below the water table, oxidizing, complexing, and mobilizing the uranium, recovering the pregnant solution at production wells, and pumping this solution to the surface for ura- 
nium extraction (Larson, 1978). This surface processing may generate some radioactive sludges (U.S. Nuclear Regulatory Commission, $1978 \mathrm{~b}$ ) ; however, the bulk of the radium-bearing residual orebody remains underground. To be suitable for in-situ leach mining, the ore deposit must be located in the saturated zone, be confined both above and below by impervious layers, have adequate permeability, and be amenable to chemical leaching (U.S. Nuclear Regulatory Commission, 1978b).

While such techniques do not generate tailings deposits at the surface, they are not without potential environmental hazards. Substances injected into the aquifer, and elements, both radioactive and non-radioactive, mobilized from the ore zone by these substances represent potential ground-water contaminants both during mining and after such operations cease. A recent report by Thompson and others (1978) discusses techniques aimed at the post-mining restoration of water quality in the affected portions of the aquifer to acceptable levels and presents results from several pilot restoration operations.

\section{CONCLUSIONS}

This report has not attempted to specifically address the question: What degree of containment is required for the storage of uranium mill tailings? An answer to this question must take into account what society regards as an acceptable risk for itself and future generations. The issue of "acceptable risk" is complex, transcending the boundaries of science and technology, and is beyond the scope of this report. What has been attempted is an outline of the pathways for environmental radiation exposure from uranium mill tailings and some of the potential long-term hydrologic and geologic consequences of various containment schemes.

Because of the 77,000 year half-life of thorium-230, the diminution of environmental effects associated with radionuclides contained in these tailings must be conceived of within the framework of geologic processes operating over geologic time. The magnitude of erosion of cover materials and tailings, and the extent of geochemical mobilization of the contained radionuclides to the atmosphere and hydro- sphere should be considered in the evaluation of the potential, long-term consequences of all proposed uranium mill tailings management plans. The period and extent of containment of radionuclides will depend upon:

(1) The technology involved in tailings' processing and in the siting and design of disposal sites.

(2) The nature of the interaction between the radionuclides and the components of the confining natural media.

(3) The rates of environmental processes such as erosion, aggradation, precipitation and evapotranspiration.

All of these factors will influence the flux of radionuclides through the environment. While the radon source term to the atmosphere will largely be a function of the depth of burial with time, the mobilization of long-lived radionuclides from the tailings by surface and ground waters and the retention of these radionuclides by soils and rocks is more complex and appears worthy of additional study.

\section{REFERENCES}

Adam, J. A., and Rogers, V. L., 1978 A classification system for radioactive waste disposal-What waste goes where: U.S. Nuclear Regulatory Commission Report NUREG-0456, $416 \mathrm{p}$.

Ambe, S., and Lieser, K. H., 1978, Coprecipitation of thorium with barium sulfate: Radiochimica Acta, v. 25 , no. 2 , p. $93-98$.

Ames, L. L., and Rai, Dhanpat, 1978, Radionuclide interactions with soil and rock media: U.S. Environmental Protection Agency, Office of Radiation Programs Report EPA 520/6-78-007A, v. 1, 306 p.

Anonymous, 1978, Formidable challenges await uranium mining: Mining Engineering, v. 30, no. 10, p. 1423.

Argonne National Laboratory, 1978, Final report of the Task Force on Uranium Mill Tailings Waste Management: Argonne National Laboratory, Environmental Impact Studies Division (June 1978), $261 \mathrm{p}$.

Austin, S. R., and Droullard, R. F., 1978, Radon emanation from domestic uranium ores determined by modifications of the closed can, gamma-only assay method: U.S. Bureau of Mines Report of Investigations no. 8264, $74 \mathrm{p}$.

Barker, F. B., and Scott, R. C., 1958, Uranium and radium in the ground water of the Llano Estacado, Texas and New Mexico: American Geophysical Union Transactions, v. 39, no. 3, p. 459-466.

Bell, K. G., 1963, Uranium in carbonate rocks: U.S. Geological Survey Professional Paper 474-A, 29 p.

Bernhardt, D. E., Johns, F. B., and Kaufmann, R. F., 1978, Radon exhalation from uranium mill tailings piles-description and verification of the measurement method: U.S. Environmental Protection 
Agency, Office of Radiation Programs, Technical Note ORP/LV-75-7 (A), $39 \mathrm{p}$.

Bondietti, E. A., 1974, Adsorption of plutonium (IV) and thorium (IV) by soil colloids: Abstracts of Annual Meeting American Society of Agronomy, p. 23.

Borrowman, S. R., and Brooks, P. T., 1975, Radium removal from uranium ores and mill tailings: U.S. Bureau of Mines Report of Investigations no. 8099, $12 \mathrm{p}$.

Brakenridge, G. R., 1978, Evidence for a cold, dry fullglacial climate in the American southwest: Quaternary Research, v. 9, p. 22-40.

Breslin, A. J., and Glauberman, H., 1970, Investigation of radioactive dust dispersed from uranium tailings piles, in, Reinig, W. C., ed., Environmental Surveillance in the Vicinity of Nuclear Facilities: Charles C. Thomas, Publisher; Springfield, Ill., p. 249-253.

Cadigan, R. A., and Felmlee, J. K., 1977, Radioactive springs geochemical data related to uranium exploration: Journal of Geochemical Exploration, v. 8, p. 381-395.

Cadigan, R. A., Felmlee, J. K., and Rosholt, J. N., 1976. Radioactive mineral springs in Delta County, Colorado: U.S. Geological Survey Open-File Report 76$223,39 \mathrm{p}$.

Charalambous, Stef., and Papastefanou, Const., 1977, On the radioactivity of fossil bones: Nuclear Instruments and Methods, v. 142, p. 581-588.

Clark, D. A., 1974, State-of-the-art: Uranium mining, milling, and refining industry: U.S. Environmental Protection Agency Report EPA-660/2-74-038, 113 p.

Clements, W. E., Barr, S., and Marple, M. L., 1978, Uranium mill tailings piles as sources of atmospheric ${ }^{222} \mathrm{Rn}$ : Los Alamos Scientific Lab Report LAUR 78-828 (preprint from Natural Radiation Environment III Symposium, Houston, Texas, April 23-28, 1978), 34 p.

Comptroller General of the United States, 1978, The uranium mill tailings cleanup: Federal leadership at last, U.S. General Accounting Office, (Rept.) EMD-78-90; June 20, 1978.

Conference of Radiation Control Program Directors, 1978, Natural radioactivity contamination problems-A report of the task force: U.S. Environmental Protection Agency (Rept.) EPA-520/4-77015.

Cook, L. M., 1978, The uranium district of the Texas Gulf Coastal Plain (Summary Paper) International Symposium on the Natural Radiation Environment III; Houston, Texas: April 23-28, 1978, p. 249250.

Cotton, F. A., and Wilkinson, G., 1966, Advanced inorganic chemistry: Wiley, New York, 1136 p.

D'Appolonia Consulting Engineers, Inc., 1977, Environmental effects of present and proposed tailings disposal practices, Split Rock Mill, Jeffrey City, Wyoming; Report 3, v. 1 and 2. Prepared for Western Nuclear, Inc. (project no. RM77-419, Oct. 1977).
Dement'yev, V. S., and Syromyatnikov, N. G., 1965, Mode of occurrence of thorium isotopes in ground waters: Geochemical International, v. 2, no. 1, p. 141-147.

Dement'yev, V. S., and Syromyatnikov, N. G., 1968, Conditions of formation of a sorption barrier to the migration of uranium in an oxidizing environment: Geochemical International, v. 5, p. 394-400.

Dilworth, Secord, Meagher and Associates Ltd., 1979, Radon production rate of Elliot Lake Soils, Report 4-Development program for radon reduction. DSMA Report 1012/1024. Prepared for Atomic Energy Control Board of Canada, $26 \mathrm{p}$.

Dodds, R. B., Jurgens, E. I., and Freitag, C. A., 1978, Retention of radioactive wastes at an operating uranium mill site: in Proceedings of Seminar on Management, Stabilisation and Environmental Impact of Uranium Mill Tailings, Albuquerque, New Mexico: July 24-28, 1978; Organisation for Economic Co-Operation and Development, Nuclear Energy Agency, Paris, France. p. 227-243.

Douglas, R. L., and Hans, J. M., Jr., 1975, Gamma radiation surveys at inactive uranium mill sites: U.S. Environmental Protection Agency-Office of Radiation Programs, Technical Note ORP/LV-75$5,97 \mathrm{p}$.

Dreesen, D. R., 1978, Uranium mill tailings-environmental implications: Los Alamos Scientific Laboratory, LASL Mini-Review, LASL 77-37, Feb. 1978, $4 \mathrm{p}$.

Dreesen, D. R., Marple, M. L., and Kelley, N. E., 1978, Contaminant transport, revegetation and trace element studies at inactive uranium mill tailings piles, in Proceedings Symposium on Uranium Mill Tailings Disposal: Colorado State University, Ft. Collins, Colo., Nov. 20-21, 1978, p. 111-139.

Duncan, D. L., Boysen, G. A., Grossman, L., and Franz, G. A., III, 1977, Outdoor radon study (19741975) - An evaluation of ambient radon-222 concentrations in Grand Junction, Colorado: U.S. Environmental Protection Agency, Office of Radiation Programs, Technical Note ORP/LV-77-1, 68 p.

Dyck, W., 1978, The mobility and concentration of uranium and its decay products in temperate surficial environments, in M. M. Kimberly, ed Short course handbook-Uranium deposits, their mineralogy and origin: Mineralogical Association of Canada (Toronto, Oct. 27-29, 1978) University of Toronto Press, p. 57-100.

Eisenbud, M., 1963, Environmental radioactivity: McGraw-Hill, New York, $430 \mathrm{p}$.

Eadie, G. G., and Kaufmann, R. F., 1977, Radiological evaluation of the effects of uranium mining and milling operations on selected ground water supplies in the Grants Mineral Belt, New Mexico: Health Physics, v. 32, p. 231-241.

Felmlee, J. K., and Cadigan, R. A., 1978a, Radium and uranium data for mineral springs in eight western states: U.S. Geological Survey Open-File Report 78-561, $45 \mathrm{p}$.

Felmlee, J. K., and Cadigan, R. A., 1978b, Determination of uranium in source rocks by using radium in 
Crystal Springs, Great Salt Lake area, Utah: U.S. Geological Survey Open-File Report 78-102, 29 p.

Ford, Bacon, and Davis Utah, Inc., 1976, Phase II-Title I, Engineering assessments of inactive uranium mill tailings: Vitro site; Salt Lake City, Utah. Prepared for the U.S. Energy Research and Development Administration, Grand Junction, Colo.

Ford, Bacon, and Davis Utah, Inc., 1977, Phase II-Title I, Engineering assessments of inactive uranium mill tailings: Prepared for the U.S. Department of Energy (formerly U.S. Energy Research and Development Administration) Grand Junction, Colorado.
GJT-2 Shiprock site, New Mexico
GJT-3 Mexican Hat site, Utah
GJT-4 Monument Valley site, Arizona
GJT-5 Tuba City site, Arizona
GJT-6 Durango site, Colorado
GJT-7 Slick Rock site, Colorado
GJT-8 Naturita site, Colorado
GJT-9 Grand Junction site, Colorado
GJT-10 New and Old Rifle sites, Colorado.
GJT-11 Maybell site, Colorado
GJT-12 Gunnison site, Colorado
GJT-13 Phillips/United Nuclear site;
Ambrosia Lake, New Mexico
GJT-14 Green River site, Utah
GJT-15 Spook site, Converse Co., Wyoming
GJT-16 Falls City site, Texas
GJT-17 Lowman site, Idaho
GJT-18 Lakeview site, Oregon
GJT-19 Riverton site, Wyoming
GJT-20 Ray Point site, Texas

Ford, Bacon, and Davis Utah, Inc., 1978, Radiation pathways and potential health impacts from inactive uranium mill tailings: Prepared for U.S. Department of Energy Report GJT-22, p.

Gary, Margaret, McAfee, Robert, Jr., and Wolf, C. L., eds., 1972, Glossary of Geology: Washington, American Geological Institute, $805 \mathrm{p}$.

Gera, Ferruccio, 1975, Geochemical behavior of longlived radioactive wastes: Oak Ridge National Laboratory Report ORNL-TM-4481, 99 p.

Germanov, A. I., Batulin, S. G., Volkov, G. A., Lisitsin, A. K., and Serebrennikov, V. S., 1958, Some regularities of uranium distribution in underground waters, Proc. Second U.N. International Conference Peaceful Uses of Atomic Energy, Geneva, 2: p. 161-177.

Gesell, T. F., and Prichard, H. M., 1975, The technologically enhanced natural radiation environment: Health Physics, v. 28, p. 361-366.

Goldsmith, W. A., Haywood, F. F., and Leggett, R. W., 1978, Transport of radon which diffuses from uranium mill tailings (Summary Paper) International Symposium on the Natural Radiation Environment III : Houston, Tex., April 23-28, 1978, p. 242-245.

Granger, H. C., 1963, Radium migration and its effect on the apparent age of uranium deposits at Ambrosia Lake, New Mexico: U.S. Geological Survey Prof. Paper 475-B, p. 860-863.
Granger, H. C., Santos, E. S., Dean, B. G., and Moore, F. B., 1961, Sandstone-type uranium deposits at Ambrosia Lake, New Mexico-an interim report: Economic Geology, v. 56, no. 7, p. 1179-1209.

Grim, R. E., 1968, Clay mineralogy (2d ed.) : McGraw Hill, New York, 596 p.

Hahn, Otto, 1936, Applied Radiochemistry: Cornell University Press, Ithaca, N.Y., 278 p.

Hammond, C. R., 1970, The elements (uranium), in Weast, R. C., ed., Handbook of Chemistry and Physics (51st ed.): The Chemical Rubber Co., Cleveland, Ohio, p. B-35.

Hans, J. M., Jr., and Douglas, R. L., 1975, Radiation survey of dwellings in Cane Valley, Arizona and Utah, for use of uranium mill tailings. U.S. Environmental Protection Agency, Technical Note ORP/LV-75-2, $37 \mathrm{p}$.

Hansen, R. O., and Huntington, G. L., 1969, Thorium movement in morainal soils of the High Sierra, California: Soil Science, v. 108, no. 4, p. 257-265.

Hare, F. K., and Thomas, M. K., 1974, Climate Canada. Wiley, Toronto, $256 \mathrm{p}$.

Harshman, E. N., 1970, Uranium ore rolls in the United States, in Proceedings Panel on Uranium Exploration Geology, Vienna, April 13-17, 1978, International Atomic Energy Agency, p. 219-232.

Harshman, E. N., 1972, Geology and uranium deposits, Shirley Basin Area, Wyoming: U.S. Geological Survey Professional Paper 745, 82 p.

Havens, R., and Dean, K. C., 1969, Chemical stabilization of the uranium tailings at Tuba City, Arizona: U.S. Bureau of Mines Report of Investigations no. $7288,12 \mathrm{p}$.

Havlik, Borivoj, Grafova, Jaraslava, and Nycova, Bedriska, 1968a, Radium liberation from uranium ore processing mill waste solids and uranium rocks into surface streams-(I) The effect of different $\mathrm{pH}$ of surface waters: Health Physics, v. 14, p. 417-422.

Havlik, B., Nycova, B., and Grafova, J., 1968b, Radium liberation from uranium ore processing mill waste solids and uranium rocks into surface streams-(II) The effect of different chemical composition of surface water: Health Physics, v. 14, p. 423-430.

Haywood, F. F., Goldsmith, W. A., Perdue, P. T., Fox, W. F., and Shinpaugh, W. H., 1977, Assessment of radiological impact of the inactive uranium-mill tailings pile at Salt Lake City, Utah: Oak Ridge National Laboratory Report ORNL/TM-5251.

Hem, J. D., 1970, Study and interpretation of the chemical characteristics of natural water (second edition): U.S. Geological Survey Water Supply Paper $1473,363 \mathrm{p}$.

Hendricks, D. W., 1977, Uranium mill tailings-storage, use and disposal problems, in Proceedings First Conference on Uranium Mining Technology, ed.: Kim, Y. S., University of Nevada, Reno, April 2429, 1977, Section XXI, 28 p.

Hendricks, D. W., 1978, Forward to U.S. Environmental Protection Agency Technical Note ORP/LV78-8 (A. Klute and D. F. Heermann, Water movement in uranium mill tailings profiles) p. iii-iv. 
Hendrie, J. M., 1978, Statement before the Subcommittee on Energy and the Environment, Committee on Interior and Insular Affairs, U.S. House of Representatives, Ninety-fifth Congress (June 27, 1978) Hearings serial no. 95-30, p. 254-263.

Herman, S. J., and Langmuir, D., 1978, Thorium complexes in natural waters: [Abs.], Geological Society of America Annual Meeting, Toronto, Canada, p. 419.

Hilpert, L. S., 1969, Uranium resources of northwestern New Mexico: U.S. Geological Survey Prof. Paper $603,166 \mathrm{p}$.

Honeywell, W. R., and Kaiman, S., 1966, Flotation of uranium from Elliot Lake ores: Canadian Mining Metallurgy Bulletin, v. 69, p. 99-107.

International Atomic Energy Agency, 1976, Management of wastes from the mining and milling of uranium and thorium ores- $A$ code of practice and guide to the code. IAEA Safety Series No. 44, Vienna, 50 p.

Ivarson, K. C., 1973, Microbiological formation of basic ferric sulfates: Can. Journal of Soil Science, v. 53, p. 315-323.

Ivarson, K. C., Ross, G. J., and Miles, N. M., 1978, Alterations of micas and feldspars during microbial formation of basic ferric sulfates in the laboratory: Soil Science Society of America Journal, v. 42, no. 3, p. 518-524.

Kagan, M. S., 1967, Radon, radium, uranium and mesothorium I in mineral waters of the Rostov region: Geokhimiya Translations, pt. 2, p. 497-511.

Kaiman, S., 1977, Mineralogical examination of old tailings from the Nordic Lake Mine, Elliot Lake, Ontario: Canada Centre for Mineral and Energy Technology, Energy Research Program, Mineral Science Laboratories Report ERP/MSL 77-190 (IR), $12 \mathrm{p}$

Kaiman, S., 1978, Mineralogical examination of current Elliot Lake uranium tailings: Canada Centre for Mineral and Energy Technology, Minerals Research Program, Mineral Sciences Laboratories, Report MRP/MSL 78-83 (IR), 9 p.

Kaufmann, R. F., and Bliss, J. D., 1977, Effects of phosphate mineralization and the phosphate industry on radium-226 in ground water of central Florida: U.S. Environmental Protection Agency, Office of Radiation Programs Report EPA-520-6-77-010, $125 \mathrm{p}$.

Kaufmann, R. F., Eadie, G. G., and Russell, C. R., 1976 , Effects of uranium mining and milling on ground water in the Grants Mineral Belt, New Mexico: Ground Water, v. 14, no. 5, p. 296-308.

Kelley, N. E., 1978, Vegetational stabilization of uranium spoil areas, Grants, New Mexico: Ph.D. thesis, University of New Mexico, Los Alamos Scientific Laboratory Report LA-7624-T, 88 p.

Kirby, H. W., and Salutsky, M. L., 1964, The radiochemistry of radium: National Academy of Sciences, $\mathrm{Na}$ tional Research Council, NAS-NS 3057, 205 p.

Kluge, E., Lieser, K. H., Loc. I., and Quandt, S., 1977, Separation of $\mathrm{Th}$ (Ionium) from uranium ores in sulfuric acid and nitric acid solutions: Radiochimica Acta, v. 24, no. 1, p. 21-26.

Klute, A., and Heermann, D. F., 1978, Water movement in uranium mill tailings profiles: U.S. Environmental Protection Agency, Office of Radiation Programs, Las Vegas, Nev. Facility, Technical Note ORP/LV$78-8,82$ p.

Kochenov, A. V., Zinev'yev, V. V., and Lovaleva, S. A., 1965 , Some features of the accumulation of uranium in peat bogs: Geochemical International, v. 2, p. $65-70$.

Koehmstedt, P. L., Harley, J. N., and Davis, D. K., 1967, Use of asphalt emulsion sealants to contain radon and radium in uranium tailings: Battelle Pacific Northwest Laboratories Report BNWL-2190, 73 p.

Koide, Minoru, and Bruland, K. W., 1975, Electrodeposition and determination of radium by isotopic dilution in seawater and in sediments simultaneously with other natural radionuclides: Analytica Chimica Acta, v. 75, no. 1, p. 1-19.

Langmuir, Donald, 1978, Uranium solution-mineral equilibria at low temperatures with applications to sedimentary ore deposits: Geochimica Cosmochimica Acta, v. 42, p. 547-569.

Larson, W. C., 1978, Uranium in situ leach mining in the United States: U.S. Bureau of Mines Information Circular no. 8777,68 p.

Levins, D. M., Ryan, R. K., and Strong, K. P., 1978, Leaching of radium from uranium tailings, in Proc. Seminar on Management, Stabilisation and Environmental Impact of Uranium Mill Tailings, Albuquerque, N. Mex., July 24-28, 1978: Organisation for Economic Co-Operation and Development, Nuclear Energy Agency, Paris, France, p. 271-286.

Lush, D., Brown, J., Fletcher, R., Goode, J., and Jurgens, T., 1978, An assessment of the long-term interaction of uranium tailings with the natural environment, in Proc. Seminar on Management, Stabilization and Environmental Impact of Uranium Mill Tailings, Albuquerque, N. Mex., July 2428, 1978: OECD Nuclear Energy Agency, Paris, France, p. 373-398.

Macbeth, P. J., Jensen, C. M., Rogers, V. C., and Overmeyer, R. F., 1978, Laboratory research on tailings stabilization methods and their effectiveness in radiation containment: Prepared by Ford, Bacon, and Davis Utah, Inc. for U.S. Department of Energy, Grand Junction, Colo. Report GJT-21.

Martin, J. B., 1978, Update of NRC mill licensing activities: Proceedings of Uranium Industry Seminar, Grand Junction, Colo.; Oct. 17-18, 1978, U.S. Department of Energy, Grand Junction, Colo., GJO-108 (78), p. 219-229.

Martin, J. B., and Miller, H. J., 1978, Generic environmental impact statement on U.S. uranium milling industry, in Proc. Seminar on Management, Stabilisation and Environmental Impact of Uranium Mill Tailings, Albuquerque, N. Mex., July 24-28, 1978: Organisation for Economic Co-Operation and Development, Nuclear Energy Agency, Paris, France, p. 453-468. 
Masuda, Kuniyoshi, and Yamamoto, Takashi, 1971, Studies on environmental contamination by uranium, (2) Adsorption of uranium on soil and its desorption: Journal Radiation Research, v. 12, p. 94-99.

Maysilles, J. H., Nichols, I. L., and Seidel, D. C., 1978, Extracting uranium from low grade ore from the Coso Mountains, Calif.: U.S. Bureau of Mines Report of Investigations no. 8306, $14 \mathrm{p}$.

Means, J. L., Crerar, D. A., and Duguid, J. O., 1978, Migration of radioactive wastes : radionuclide mobilization by complexing agents: Science, v. 200, no. 4349, p. 1477-1481.

Merritt, R. C., 1971, The extractive metallurgy of uranium: Colorado School of Mines Research Institute, Golden, $576 \mathrm{p}$.

Middlesworth, L. V., 1978, Radium and thorium with barium in micronodules of cattle thyroids (Summary Paper) Intl. Symp. on the Natural Radiation Environment III: Houston, Tex., April 23-28, 1978, p. 125-127.

Moffett, D., 1976, The disposal of solid wastes and liquid effluents from the milling of uranium ores: Canada Centre for Mineral and Energy Technology, Minerals Research Program, Mining Research Laboratories Report 76-19, $76 \mathrm{p}$.

Moffett, D., and Tellier, M., 1977, Uptake of radioisotopes by vegetation growing on uranium mill tailings: Canada Centre for Mineral and Energy Technology, Minerals Research Program, Mining Research Laboratories Report MRP/MRL 77-6 (J) Revised, 15 p.

Moffett, D., and Tellier, M., 1978, Radiological investigations of an abandoned uranium tailings area: Journal of Environmental Quality, v. 7, no. 3, p. 310-314.

Moffett, D., Zahary, G., Campbell, M. C., and Ingles, J. C., 1977, CANMET's environmental and process research on uranium: Canada Centre for Mineral and Energy Technology, Minerals and Energy Rescarch Programs, Mining Research Laboratories, Mineral Sciences Laboratories Report 77-53, 29 p.

Mooney, B. L., and Scott, A. G., 1978, Radium content of Elliot Lake sand deposits compared with other Ontario sands: Abstracts, Geological Society America Annual Meeting, Toronto, Canada, p. 459.

Moore, W. S., and Reid, D. F., 1973, Extraction of radium from natural waters using manganese-impregnated acrylic fibers: Jour. Geophys. Research, v. 78 , no. 36 , p. $8880-8886$.

Morse, R. H., 1970, The surficial geochemistry of radium, radon and uranium near Bancroft, Ontario with application to prospecting for uranium: Ph.D. thesis, Queen's University, Kingston, Ontario, Canada, $154 \mathrm{p}$.

Motica, J. E., 1977, Uranium exploration, in Proc. First Conf. on Uranium Mining Technology, ed. Kim, Y. S.: University of Nevada, Reno, April 24-29, 1977, Section II, 27 p.

Mutschler, P. H., Hill, J. J., and Williams, B. B., 1976, Uranium from the Chattanooga Shale-Some problems involved in development: U.S. Bureau of Mines Information Circular no. 8700, 85 p.
Nelson, J. D., and Shepard, T. A., 1978, Evaluation of long-term stability of uranium mill tailing disposal alternatives: Final report, contract no. 31-109-384199, Geotechnical Engineering Program, Colorado State University for Argonne National Laboratories, April 1978, 337 p.

Papastefanou, C., and Charalambous, Stef., 1978, Ra226 leaching from fossil bones: Nuclear Instruments and Methods, v. 141, p. 599-601.

Perel'man, A. I., 1972, Geochemistry of elements in the supergere zone: Translated from Russian, Israel Program for Scientific Translations, Jerusalem, 1977.

Raicevic, D., 1978, Decontamination of Elliot Lake uranium tailings: Canada Centre for Mineral and Energy Technology, Minerals Research Program; Mining Research Laboratories Report MRP/MSL 78-120 (OP \& J), 26 p.

Ramsey, William, 1976, Radon from uranium mill tailings-A source of significant radiation hazard?: Environmental Management, v. 1, no. 2, p. 139-145.

Rankama, Kalervo, and Sahama, Th. G., 1950, Geochemistry: University of Chicago Press, $912 \mathrm{p}$.

Reed, A. K., Meeks, H. C., Pomeroy, S. E., and Hale, V. Q., 1976, Assessment of the environmental aspects of uranium mining and milling: U.S. Environmental Protection Agency Report EPA-600/7-76$036,59 \mathrm{p}$.

Robertson, D. S., 1962, Thorium and uranium variations in the Blind River ores: Economic Geology, v. 57, p. 1175-1184.

Rogers, J. J. W., and Adams, J. A. S., 1969, Thorium, in Wedepohl, K. H., ed., Handbook of geochemistry: v. II/1, chap. 90 .

Ryon, A. D., Hurst, F. J., and Seeley, F. G., 1977, Nitric acid leaching of radium and other significant radionuclides from uranium ores and tailings: Oak Ridge National Laboratory Report ORNL/TM-5944, 37 p.

Schiager, K. J., 1974, Analysis of radiation exposures on or near uranium mill tailings piles: Radiation Data and Reports, U.S. Environmental Protection Agency, Office of Radiation Programs, v. 15, no. 7, p. 411-425.

Schiager, K. J., 1977, Radwaste radium-radon risk, in Proceedings Workshop on Policy and Technical Issues Pertinent to the Development of Environmental Protection Criteria for Radioactive Waste, Albuquerque, April 12-14, 1977 : U.S. Environmental Protection Agency, Office of Radiation Programs Report ORP/CSD-77-2, p. 2-45 to 2-81.

Schmidtke, N. W., Averill, D., Bryant, D. N., Wilkinson, P., and Schmidt, J. W., 1978, Removal of ${ }^{226} \mathrm{Ra}$ from tailings pond effluents and stabilization of uranium mine tailings-bench and pilot plant studies, in Proceedings Seminar on Management, Stabilisation and Environmental Impact of Uranium Mill Tailings, Albuquerque, N. Mex., July 24-28, 1978, OECD Nuclear Energy Agency, Paris, France, p. 299-315.

Schumm, S. A., 1963, The disparity between present rates of denudation and orogeny, U.S. Geological Survey Professional Paper 454-H, table 1, 13 p.

Sears, M. B., Blanco, R. E., Dahlman, R. D., Hill, G. S., 
Ryon, A. D., and Witherspoon, J. P., 1975, Correlation of radioactive waste treatment costs and the environmental impact of waste effluents in the nuclear fuel cycle for use in establishing "as-low-aspracticable" guides-milling of uranium ores: Oak Ridge National Laboratory Report ORNL/TM-4903, v. $1,291 \mathrm{p}$.

Sedlet, Jacob, 1966, Radon and Radium, in Kolthoff, I. M. and Elving, P. J., eds., Treatise on Analytical Chemistry, pt. 2: v. 4, Wiley-Interscience, New York, p. 219-366.

Seeley, F. G., 1976, Problems in the separation of radium from uranium ore tailings: Hydrometallurgy, v. 2, p. 249-263.

Shapiro, J., 1972, Radiation protection: Harvard Univ. Press, Cambridge, Mass., 339 p.

Shearer, S. D., Jr., 1962, The leachability of radium226 from uranium mill waste solids and river sediments: Ph.D. thesis, University of Wisconsin, $162 \mathrm{p}$.

Shearer, S. D., Jr., and Lee, G. F., 1964, Leachability of radium-226 from uranium mill solids and river sediments: Health Physics, v. 10, p. 217-227.

Sigler, W. F., Helm, W. T., Angelovic, J. W., Linn, D. W., and Martin, S. S., 1966, The effects of uranium mill wastes on stream biota: Utah Agricultural Experimental Station Bulletin 462, Utah State University, Logan, Utah, 76 p.

Skeaff, J. M., 1977, Distribution of radium-226 in uranium mill tailings: Canada Centre for Mineral and Energy Technology, Minerals Research Program, Mineral Sciences Laboratories Report MRP/MSL 77-340, $20 \mathrm{p}$.

Smith, S. E. and White, P. A., 1969, Review of uranium ore processing research: Canadian Mining Journal, v. 90 , no. 5 , p. $71-74$.

Szalay, A., 1964, Cation exchange properties of humic acids and their importance in the geochemical enrichment of $\mathrm{UO}_{2}{ }^{++}$and other cations: Geochimica et Cosmochimica Acta, v. 28, p. 1605-1614.

Tanner, A. B., 1964a, Radon migration in the grounda review, in Adams, J. A. S., and Lowder, W. M., eds., The Natural Radiation Environment: University of Chicago Press, p. 161-190.

Tanner, A. B., 1964b, Physical and chemical controls on distribution of radium-226 and radon-222 in ground water near Great Salt Lake, Utah, in Adams, J. A. S. and Lowder, W. M., eds., The Natural Radiation Environment: University of Chicago Press, p. 253-276.

Thompson, W. E., Rouse, G. E., Swarzenski, W. V., Carrington, O. F., Warner, D. L., and Pyrih, R. Z., 1978, Ground-water elements of in situ leach mining of uranium: Prepared for U.S. Nuclear Regulatory Commission, NUREG/CR-0311, 173.

Titayeva, N. A., 1967, Association of radium and uranium with peat: Geochemistry International, v. 4, no. 6, p. 1168-1174.

Titayeva, N. A., Taskayev, A. I., Ovchenkov, V. Ya., Aleksakhin, R. M., and Shuktomova, I. I., 1977, $\mathrm{U}$, Th and $\mathrm{Ra}$ isotope compositions in soils in prolonged contact with radioactive stratal waters: Geochemistry International, v. 14, no. 5, p. 57-63.
Travis, C. C., Cotter, S. J., Watson, A. P., Randolph, M. L., McDowell-Boyer, L. M., and Fields, D. E., 1979, A radiological assessment of $\mathrm{Rn}-222$ released from uranium mills and other natural and technologically enhanced sources: Prepared for the U.S. Nuclear Regulatory Commission by Oak Ridge National Laboratory, NUREG/CR-0573 (ORNL/ NUREG-55), $216 \mathrm{p}$.

Tsivoglou, E. C., Shearer, S. D., Jr., Jones, J. D., and Clark, D. A., 1960, Estimating human radiation exposure on the Animas River: Journal American Water Works Association, v. 52, p. 1271-1290.

U.S. Atomic Energy Commission, 1974, Environmental survey of the uranium fuel cycle-Report: WASH1248.

U.S. Department of Energy, 1978, Statistical data of the uranium industry, Jan. 1, 1978-Report: GJO$100(78)$.

U.S. Department of Health, Education and Welfare, 1970, Radiological Health Handbook: Bureau of Radiological Health; Rockville, Md, 458 p.

U.S. Department of the Interior, 1976, Final environmental statement, Sherwood Uranium Project, Spokane Indian Reservation: Bureau of Indian Affairs, Portland, Oreg., v. 1-2.

U.S. Environmental Protection Agency, 1971, Evaluation of the impact of the Mines Development, Inc., Mill on water quality conditions in the Cheyenne River: U.S. Environmental Protection Agency, Region VIII, Denver, Colo., Sept. 1971, 46 p.

U.S. Environmental Protection Agency, 1973, Environmental analysis of the uranium fuel cycle, pt. I, Fuel Supply: Office of Radiation Programs-Report EPA-520/9-73-003-B, $190 \mathrm{p}$.

U.S. Environmental Protection Agency, 1975, Water quality impacts of uranium mining and milling activities in the Grants Mineral Belt, New Mexico: U.S. Environmental Protection Agency, Region VI, Dallas, Tex. Report EPA 906/9-75-002, 188 p.

U.S. Environmental Protection Agency, 1976a, Environmental radiation protection requirements for normal operations of activities in the uranium fuel cycle (40 CFR 190) Final environmental statement: U.S. Environmental Protection Agency, Office of Radiation Programs-Report EPA-520/4-76-016, v. I, $236 \mathrm{p}$.

U.S. Environmental Protection Agency, 1976b, Environmental analysis of the uranium fuel cycle, pt. IV, supplementary analysis, 1976: U.S. Environmental Protection Agency, Office of Radiation Programs, Report EPA 520/4-76-017, 130 p.

U.S. Environmental Protection Agency, 1977, Radiological quality of the environment in the United States, 1977: Office of Radiation Programs-Report EPA 520/1-77-009, 295 p.

U.S. Environmental Protection Agency, 1978a, Hazardous waste-proposed guidelines and regulations and proposal on identification and listing: Federal Register, v. 43 , no. 243 , Dec. 18,1978 , p. 58945-59028.

U.S. Environmental Protection Agency, 1978b, Draft background document, radioactive waste (BD-6) ; 
Resource Conservation and Recovery Act, Subtitle C-Hazardous waste management: U.S. Environmental Protection Agency, Office of Solid Waste, Dec. 15, 1978, $38 \mathrm{p}$.

U.S. Forest Service, 1978, Draft environmental statement related to the operation of the Homestake Mining Company Pitch Project: Prepared jointly by U.S. Forest Service, Delta, Colo., and U.S. Nuclear Regulatory Commission,

U.S. Nuclear Regulatory Commission, 1977a, Branch position-uranium mill tailings management, Fuel Processing and Fabrication Branch: May 13, 1977, 3 p.

U.S. Nuclear Regulatory Commission, 1977b, Design, construction, and inspection of embankment retention systems for uranium mills: Regulatory guide 3.11, revision 2, Dec. 1977, 9 p.

U.S. Nuclear Regulatory Commission, 1978a, Final environmental statement related to the United $\mathrm{Nu}$ clear Corporation Morton Ranch, Wyoming uranium mill: NUREG-0532.

U.S. Nuclear Regulatory Commission, 1978b, Final environmental statement related to operation of Wyoming Mineral Corporation Irigaray solution mining project: NUREG-0481.

U.S. Nuclear Regulatory Commission, 1978c, Final environmental statement related to operation of Highland uranium solution mining project: NUREG0489.

U.S. Nuclear Regulatory Commission, 1978d, Final environmental statement related to operation of Sweetwater uranium project: NUREG-0505.

U.S. Nuclear Regulatory Commission, 1978e, Draft environmental statement related to operation of White Mesa uranium project: NUREG-0494.

U.S. Nuclear Regulatory Commission, 1979a, Draft generic environmental impact statement on uranium milling: NUREG-0511.

U.S. Nuclear Regulatory Commission, 1979b, Final en- vironmental statement related to the operation of the Moab uranium mill: NUREG-0453.

Van Devender, T. R., 1977, Holocene woodlands in the southwestern deserts: Science, v. 198, p. 189-192.

Vdovenko, V. M., and Dubasov, Yu. V., 1975, Analytical chemistry of radium: Wiley, New York, $198 \mathrm{p}$.

Watkin, E. M., and Winch, J. E., 1973, Composted organic wastes, sewage sludges, and rock phosphate for amelioration of acid uranium mill tailings, in Proc. International Conference on Land for Waste Management, Ottawa, Canada, Oct. 1973: p. 48-56.

West, S. W., 1972, Disposal of uranium mill effluent by well injection in the Grants area, Valencia County, New Mexico: U.S. Geological Survey Professional Paper 386-D, 28 p.

Whicker, F. W., 1978, Biological interactions and reclamation of uranium mill tailings, in Proc. Symp. on Uranium Mill Tailings Disposal: Colorado State University, Fort Collins, Colo., Nov. 20-21, 1978; p. 141-153.

Wiles, D. R., 1978, The leaching of radium from Beaverlodge tailings, in Proc. Seminar on Management, Stabilisation and Environmental Impact of Uranium Mill Tailings, Albuquerque, N. Mex., July 2428, 1978: OECD Nuclear Energy Agency, Paris, France, p. 245-257.

Wilkening, M. H., 1974, Radon-222 from the island of Hawaii-Deep soils are more important than lava fields or volcanoes: Science, v. 183 , no. 4123 , p. 413415.

Winograd, I. J., 1974, Radioactive waste storage in the arid zone: EOS, American Geophysical Union Transactions, v. 55, no. 10 , p. 884-894. (Discussion in EOS, v. 57 , no. 4 , p. 178, 215-216.)

Wullstein, L. H., 1978, Vegetative stabilization report (Appendix A in Macbeth, and others, 1978, Laboratory research on tailings stabilization methods and their effectiveness in radiation containment: Prepared for U.S. Department of Energy, Grand Junction, Colo., Rept. GJT-21). 